\title{
Athens and Apolline Polyphony in Bacchylides' Ode 16
}

\author{
Margaret Foster*
}

"Despite the address to Pythian Apollo and the reference to paeans and choirs of Delphians, this ode is certainly not a paean since its main part (13-35) has nothing to do with Apollo."1 So begins Herwig Maehler's commentary on Bacchylides' Ode 16 (= Dithyramb 2). Ode 16 comprises a single triad:

[HPAK $\Lambda \mathrm{H} \Sigma($ VEL $\triangle$ HIANEIPA?)

$\mathrm{EI} \Sigma \Delta \mathrm{E} \Lambda \Phi O Y \Sigma]$

... .]!० . . . . . .

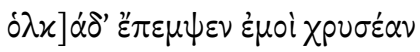

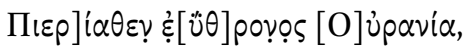

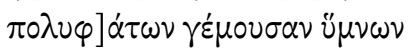

5

.....] ]

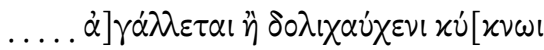

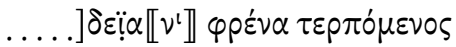

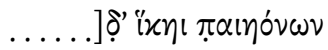

$\ddot{\alpha} \nu \theta \varepsilon \alpha \pi \varepsilon \delta 0 \circ \chi \nu \varepsilon i v$,

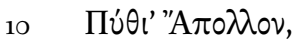

$\tau o ́ \sigma \alpha \chi \varnothing \rho \circ i \Delta \varepsilon \lambda \varphi \omega \hat{\nu}$

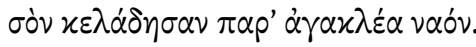

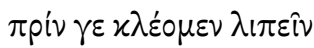

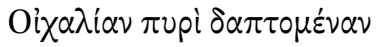

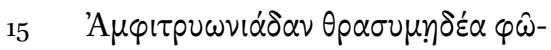

* I am grateful to audiences at UC Berkeley, Indiana University, University of Michigan, and the Society for Classical Studies for their comments on previous versions of this paper. I wish to thank especially Leslie Kurke and Naomi Weiss for their careful readings of earlier drafts of the paper. Their perceptive and generous suggestions have made it better.

1 Maehler 2004: 164. 


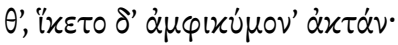

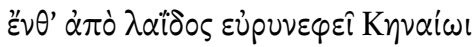

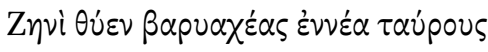

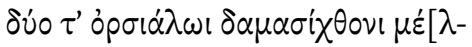

20

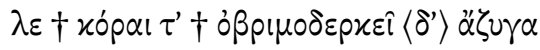

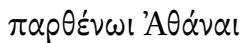

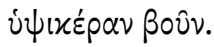

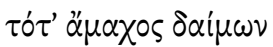

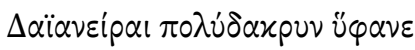

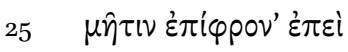

$\pi \dot{u}^{\prime} \theta \varepsilon \tau^{\prime} \alpha \gamma \varepsilon \lambda \lambda^{\prime} \alpha \nu \tau \alpha \lambda \alpha \pi \varepsilon \nu \theta \varepsilon \dot{\varepsilon} \alpha$,

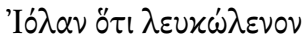

$\Delta$ iòs viòs $\alpha \dot{\tau} \tau \alpha \beta \beta \mu \mu \alpha \alpha \alpha \varsigma$

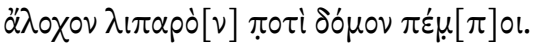

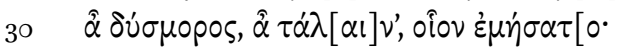

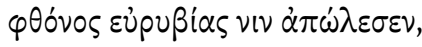

$\delta v o ́ \varphi \varepsilon \delta ́ v \tau \varepsilon x \alpha ́ \lambda \nu \mu \mu \alpha \tau \omega \hat{\omega}$



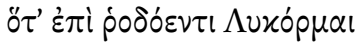

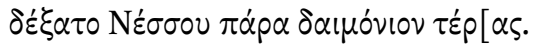

\section{[HERACLES (or DEIANEIRA?); FOR DELPHI]}

... since fine-throned Ourania has sent me from Pieria a golden cargo ship loaded with renowned songs ... upon the banks of the flowery Hebrus

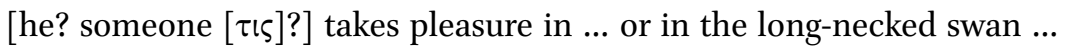
delighting his heart ... you come to pursue flowers of paeans, Pythian Apollo, as many as the choruses of Delphians are accustomed to sing beside your far-famed temple. But, first, we sing how the son of Amphitryon, the bold-planning mortal, left Oechalia devoured by fire and arrived at the promontory washed by waves; there from his spoils he was about to sacrifice nine deep-bellowing bulls to Zeus of Cenaeum, lord of spreading clouds, and two to the sea-rouser and earth-shaker, and a high-horned cow, unyoked, to the maiden Athena with the mighty glance. At that moment an irresistible daimon wove for Deianeira a sorrowful shrewd plan when she heard the distressing news that the intrepid son of Zeus was sending to his gleaming home white-armed Iole to be his wife. Ah, ill-fated, wretched woman, what a plan she devised!Widely powerful jealousy destroyed her and the murky veil covering what was to 
come when by the banks of rosy Lycormas she received from Nessus the fateful marvel. ${ }^{2}$

Ode 16's fragmentary strophe ranges over several figures and locations, including the Muse Ourania and Pieria and a swan at the Hebrus River, before coming to rest on an appeal to Pythian Apollo to pursue "flowers of paeans" (8-9) and a closing image of Delphian choruses singing around the god's temple. The poem then abruptly switches gears: with the onset of the antistrophe, it launches into a mythic narrative from which it never returns. The antistrophe and epode narrate the myth of Heracles and Deianeira or, more precisely, the events leading up to the hero's death at his wife's unwitting hands. The antistrophe centers on Heracles as he prepares to sacrifice to the gods at Cenaeum just before he is poisoned by Deianeira's gift of the deadly robe. The epode turns to Deianeira, her new awareness of Iole and resulting jealousy, and her ignorance of the future and true nature of the gift she once accepted from the centaur Nessus at the Lycormas River.

Maehler's paradoxical statement ("Despite the address to Pythian Apollo and the reference to paeans ... this ode is certainly not a paean") captures well Ode 16's resistance to generic classification along clear-cut taxonomic lines. Nevertheless, a broad scholarly consensus prevails concerning a number of the poem's features. First, since the poem's discovery in the late nineteenth century, scholars have almost unanimously agreed that the absent Apollo invoked in the strophe is returning to Delphi from his winter residence among the mythical, northern Hyperboreans. Second, based on the assumption that the ode's internal chorus is awaiting Apollo's return from the Hyperboreans to Delphi, most scholars also understand Delphi as the site of the ode's present performance. ${ }^{3}$ Third, since Dionysus is said to preside over Delphi in Apollo's absence, scholars argue that Dionysus must be the god whom Ode 16 ultimately celebrates. $^{4}$

This reconstructed scenario for Ode 16 - that a chorus, after signaling Apollo's imminent arrival, sings in the meantime for Dionysus - seems to hold up from the perspective of genre. Plutarch records that while Apollo is absent from Delphi during the three winter months, the Delphians leave off performing

2 The Greek text is from Maehler 2003, although at the end of line 10 I replace Maehler's period with a comma. The translation, discussed in detail below, is my own.

3 On Delphi as the site of Ode 16's performance, see, e.g., Burnett 1985: 125; Platter 1994: 337; Rutherford 1994-1995: 117; Maehler 1997: 150-151 and 2004: 165-166; Pfeijffer 1999a: 55; Wilson 2000: 322 n. 115; Fearn 2007: 237.

4 See, e.g., Fearn 2007: 237. 
paeans with their sacrifices and instead sing dithyrambs in honor of Dionysus (Mor. 389c). Accordingly, scholars will point to the strophe's "paeanic-like elements," including its reference to "flowers of paeans" (8-9), before assigning the extended mythic narrative of the antistrophe and epode to Dionysus' genre of dithyramb. ${ }^{5}$ Ian Rutherford captures well this understanding of the underlying myth and ritual context of Ode 16 and its implications for the poem's genre(s) when he designates Ode 16 as "a vital piece of evidence for a general contrast between paeans and dithyrambs in the fifth century." 6

Alongside discussions of Apollo and Dionysus' Delphic time-share and their respective genres, a debate has raged over the intertextual relationship between Ode 16 and Sophocles' Trachiniae. ${ }^{7}$ For the mythic narrative of Bacchylides' poem not only closely coincides with the plot of the tragedy but also exhibits thematic and dictional parallels strongly suggesting that one text sought to evoke the other. The most convincing arguments have demonstrated that Trachiniae is the earlier text and that Bacchylides presents a version of the myth of Heracles and Deianeira that meticulously corresponds to, even requires knowledge of, the idiosyncratic version of the myth found in the Sophoclean tragedy. ${ }^{8}$ And yet while many scholars agree on Trachiniae's chronological priority, far less attention has been devoted to considering the function of such a farreaching intertextual allusion to a tragedy within a nondramatic lyric poem. ${ }^{9}$

Further, Ode 16's extensive appropriation of Trachiniae has never been convincingly related to the belief that the ode was performed at Delphi. Scholars will point to a loose association between the poem's tragic material and Dionysus' presence at Delphi, but this vague Dionysiac connection does not satisfactorily explain why Bacchylides should wish for his lyric poem to interact so precisely with Trachiniae in particular. The result is that, in the secondary literature, Ode 16 is devoid of any compelling ritual occasion for its performance. What is more, from a formal perspective, Ode 16 also remains a severely

5 Quotation from Rutherford (1994-1995: 116). Maehler (1997:160) suggests that lines 1-10 could either be a cletic hymn or a paean. By contrast, Burnett (1985: 123) seems to view the entire poem as a paean. For the connection between mythic narratives and the genre of dithyramb, see especially D'Alessio 2013.

6 Rutherford 1994-1995: 117. For similar sentiments, see Campbell 1992: 213 and Maehler 2004: 165 .

7 Kenyon 1897: 148; Stoessl 1945: 58-63; Kamerbeek 1959: 5-7; Schwinge 1962: 130-132; Hoey 1979; Burnett 1985: 194-195 n. 27; March 1987: 62-66; Davies 1991: xxxii-xxxiii; Maehler 1997: 151-156 and 2004: 166-167; Pfeijffer 1999a: 51-55; Carawan 200o; Riemer 200o; Kyriakou 2011: 535-538.

8 See especially March 1987: 62-66; Pfeijffer 1999a: 52; Maehler 2004: 167. For the various ways in which Ode 16 alludes to Trachiniae, see Part II below.

9 Pfeijffer 1999a presents an exception to this tendency. 
disjointed poem: its strophe recalling Apollo from the Hyperboreans seems irreconcilably at odds with the "dithyrambic" antistrophe and epode that is both in honor of Dionysus and somehow connected to Sophocles' Trachiniae. These interconnected problems merit a careful reexamination of Ode 16, especially its fragmentary strophe, and merit as well a concerted effort to situate the poem within the evolving and dynamic generic economy of fifth-century choral song.

This paper offers a new reading of Ode 16 and argues that the poem does not await Apollo's Delphic homecoming and is not a dithyrambic poem in honor of Dionysus. The paper falls into two parts. Part I begins with a formal analysis of the fragmentary strophe followed by a consideration of its relationship to the antistrophe and epode. Just as the poem itself is divided into three stanzas, so too the opening strophe consists of three scenes or vignettes. These vignettes map onto three distinct sites, Pieria (1-4), the Hebrus River (5-7), and Delphi (8-12). Taking each of these vignettes in turn, I will argue through a series of close readings that, contrary to the established view, the strophe does not relate an episode from the myth of Apollo's return from the Hyperboreans nor does it indicate that the poem's present performance takes place at Delphi. Rather than tracking Apollo's own movements, the strophe showcases the movement of music by presenting a sequence of generically distinct songs, all tied to discrete geographical locations and all sung in honor of Apollo. When we turn to the opening of the antistrophe, we find that this sequence of songs continues here as Bacchylides shifts from simply listing different song types to presenting an entire song itself, that is, the song comprising the mythic narrative of the antistrophe and epode. Viewed from this angle, Ode 16 can be seen as a polyphony of independent songs, all, including the mythic narrative, sung in honor of Apollo, and yet all presented as in some sense autonomous and separate from one another. ${ }^{10}$

Part II contextualizes this sequence of autonomous songs by suggesting a new ritual occasion for Ode 16, an occasion that places the poem's performance in Athens, not Delphi. Other scholars have mentioned Athens in passing as the possible site of Ode 16's performance, but I offer a more specific context, the Athenian Thargelia. This proposal brings with it a new way of understanding

10 My use of the term polyphony derives from its technical sense: Merriam-Webster defines polyphony as "a musical composition employing two or more simultaneous but relatively independent melodic lines." I modify this definition slightly in reference to Ode 16: its "independent melodic lines" are the autonomous songs (note the $\pi 0 \lambda \nu \varphi] \alpha \dot{\tau} \omega \nu . . . \ddot{\nu} \mu \nu \omega \nu$ at line 4) within it that, although they do not occur simultaneously, all share the space of a single poem. 
Ode 16's explicit allusions to Sophocles' Trachiniae and, more generally, to the genre of tragedy. After reviewing Ode 16's connection to Trachiniae, I will conclude by suggesting that the new formal and historicizing interpretations of Ode 16 explored here allow us to glimpse a larger cultural phenomenon at work: they allow us to understand the poem as a conscious response to tragedy as the "super-genre" of the Athenian empire and to view the poem itself as a vehicle for moving this distinctively Athenian generic form beyond the borders of Attica. ${ }^{11}$

\section{Part I: A Cargo Ship of Songs}

\section{Vignette 1: Pieria}

The ode's own point of departure coincides with the departure of a cargo ship, dispatched from Pieria and brimming with songs (1-4):

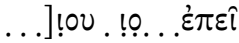

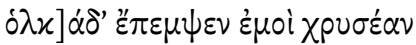

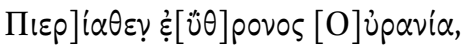

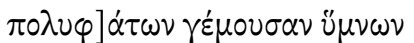

since fine-throned Ourania has sent me from Pieria a golden cargo ship loaded with renowned songs

Boris Maslov's work on Pindar's epinicia allows us to make two crucial observations about the metapoetic function of these opening lines. First, in contrast to Pindar, Bacchylides always explicitly names the Muse he calls upon to sanction his poetry, and the name he most often bestows upon her is Ourania. ${ }^{12}$ As Maslov asserts, this tactic operates as a metapoetic way for Bacchylides to signal, and so authorize, his individual poetic "brand."13 By announcing that it is his personal Muse Ourania who has sent "hymns to me," Bacchylides announces his singular poetic authority. ${ }^{14}$

Second, Maslov's insights into the semantics of $u_{\mu \nu}{ }^{\circ}$ s illuminate the nature of the songs $(\ddot{u} \mu \nu \circ, 4)$ stowed aboard this cargo ship. Even as $\ddot{u} \mu \nu \circ$ comes

\footnotetext{
11 I borrow the term "super-genre" in reference to tragedy from Weiss (this volume).

12 Maslov 2015: 99-100.

13 Quotation from Maslov 2015: 100.

14 The announcement of a Greek lyric poet's "brand" is, as Maslov (2015: 99-100) notes, a sphragis-like moment. Since Bacchylides is showcasing in this way his individual poetic authority, દ̇uoi (2) must refer to the poet and not to the chorus (contra Maehler 2004: 168).
} 
to refer generally to songs of praise in the fifth century, it never fully loses its associations with choral lyric and cult. ${ }^{15}$ These associations suggest that we are meant in Ode 16 to imagine the Muse's freight as songs that are tied to a cult location and that anticipate performances by choruses, associations that the unmarked $\alpha$ oı $\delta$ ', for instance, would not necessarily convey. Yet more pertinent

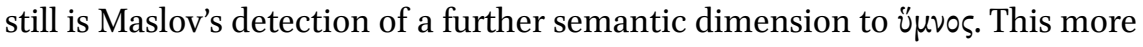
enigmatic nuance is activated when the word appears within a particular cluster of textual elements found in several Pindaric epinicia. In Olympian 1 and Nemean 1, $\ddot{u} \mu \nu 0 \varsigma$ occurs at the beginning of the poem and as part of a construction that includes $-\theta \varepsilon \nu$ (whence) + epithet + $\ddot{\mu} \mu \nu \circ(O .1 .8-10$ and $N .1 .4-6) .{ }^{16}$

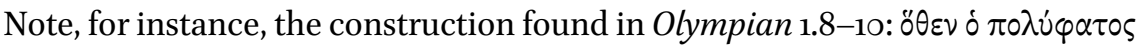

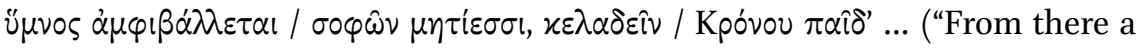
renowned $\ddot{u} \mu \nu \circ$ s enfolds the thoughts of wise men so that they sing the child of Cronus ..."). Similarly, at the opening of Nemean 3, a ü $\mu \nu 0 \varsigma$ (again with an epi-

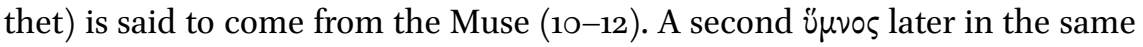
poem travels out from Zeus' cult to its human chorus $\left(65^{-66)} \cdot{ }^{17}\right.$ In these examples, the word's general cultic associations are more explicitly defined: $u \mu \nu \circ \varsigma$ is not just connected to cult but is shown to derive from cult.

This observation has significant implications, as Maslov recognizes. For it exposes how a ü $\mu \nu \circ \varsigma$ can perform an agent-like function as it mediates between its divine cultic origin and the world of its poet and chorus. Moreover, it reveals how, in its role as mediator, a ü $\mu \nu \circ$ is conceived of as something initially independent of and prior to the poet's own creation. That is, in these epinician contexts, ن̌ $\mu \nu \circ \varsigma$ possesses a striking degree of autonomy. ${ }^{18}$ Such a semantic force produces a paradox insofar as Pindar can foreground a ü $\mu \nu \circ \varsigma^{\prime}$ autonomy and agency within an epinician at the same time as he asserts his own active role as poet in the epinician's creation..$^{19}$ Maslov accounts for this paradox by positing a twofold signification of the meaning of ü $\mu \nu \circ$ s: the word seems simultaneously to denote the "text that evokes, and instantiates, goodwill/graciousness/praise"

15 Maslov 2015: 292-293, 302.

16 The two Pindaric examples also both exhibit a present-tense finite verb + purpose infinitive.

17 For these lines, see Maslov 2015: 304.

18 Thus Maslov (2015: 305) calls the poet both an "epiphenomenon" and a "passive conduit" of the üpvos. See too Maslov 2015: 303: "hymnos belongs to the divine sphere; it is then appropriated by the poet who, finally, adapts it to real-life performance. Notably, even at this last stage of materialization hymnos retains an autonomy and agent-like quality: it possesses the chorus" (emphasis in original).

19 Maslov 2015: 304. 
as well as "goodwill, disposition to praise itself." 20 That is, because ü $\mu \nu \circ \varsigma$ signifies the verbal act of divinely generated praise, and not just the text that is the product of that act, the word can point to or embody a stage in its own evolution that predates the eventual poetic composition of the $\tilde{u} \mu \nu \circ \varsigma$ by the poet.

To return to Ode 16 , I draw attention to how the ü $\mu v 0$ เ of line 4 share a number of formal features with these epinician instances of the word. Ode 16's ü $\mu$ vor also appear at the opening of the poem and also arise from a specific cultic loca-

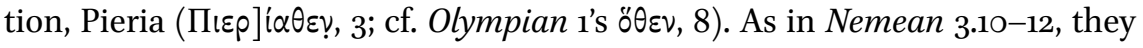
announce that they come from a Muse and, as in Olympian 1.8, they seem to be called $\pi \circ \lambda$ í $\varphi$ $\tau 0$. Given these formal similarities, I suggest that Bacchylides' u $\mu \nu$ o express a comparable semantic nuance to the Pindaric examples. For Ode 16 's $u$ u $\nu$ เ also perform a mediating, agent-like function, as the image of the ship of songs sailing out from Ourania to the poet captures so well. Moreover, as in Pindar's epinicia, these ü $\mu \nu$ o are initially independent of the poet, since they are sent to him by Ourania. As such, they can be seen to possess a degree of autonomy. In fact, I would extend Maslov's argument further here and argue that in the case of Ode 16, which presents a plurality of ü $\mu \nu$ ol, we should understand these songs not merely as autonomous in relation to the poet but also as autonomous in relation to one another.

It is perhaps because of this shared semantic nuance with Pindar's epinicia that the opening of Ode 16 achieves its epinician resonance. In addition to sharing the cluster of formal features that also attend the $\ddot{\mu} \mu \nu$ of olympian 1 and Nemeans 1 and 3, Bacchylides' choice of the word $\dot{\partial} \lambda x \alpha$ s (cargo ship, 2) may also trigger Ode 16's initial epinician sound. The word is extremely rare in poetry but does occur prominently in the opening lines of Nemean 5 where Pindar connects it to his own song. In short, by linking o $\lambda x \alpha \dot{\alpha} \varsigma$ so closely with

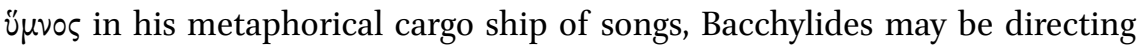
us to apply to these particular ü $\mu \nu$ o the associations of autonomy and agency found in epinician. ${ }^{21}$ Maslov posits the antiquity, even the pre-Greek nature, of this semantic dimension of ü $\mu$ vos, but it may well be that this nuance comes to be associated with the genre of epinician. ${ }^{22}$ If this is the case, then Bacchylides

20 Quotation from Maslov 2015: 303.

21 In Nemean 5, Pindar enjoins his song to "go forth from Aegina on every cargo ship and

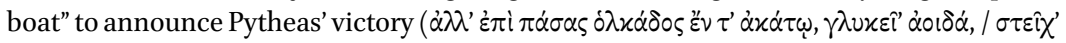
$\dot{\alpha} \pi^{\prime}$ Airivas, 2-3). Nemean 5 is an early epinician (ca. 483 BCE) and must predate Ode 16. If Bacchylides is indeed responding to this particular Pindaric image, he simultaneously inverts it: rather than a single song traveling on every ship, in Ode 16 a single cargo ship contains a multiplicity of songs. This inversion may help to signal that Bacchylides' poem is ultimately up to something different than its epinician predecessor. 
conjures this genre as a way to assert the agent-like and autonomous properties of his cargo ship of ü $\mu$ vo. ${ }^{23}$

Bacchylides thus contructs the opening of Ode 16 as a metapoetic frame in which he asserts his own literary authority. At the same time, through a cluster of dictional cues, he directs us to apply to his $u_{\mu \nu} \mathrm{r}$ a function and meaning of the word found in epinician. In so doing, Bacchylides activates $\ddot{u} \mu \nu \circ \varsigma^{\prime}$ capacity for autonomy. Yet, in so far as these $u_{\mu \nu}$ o are stored together aboard a single cargo ship, he also reveals their potential for collaboration. In this way, Ode 16's metapoetic opening establishes one of the poem's central themes: the polyphony of autonomous songs. I turn now to trace this theme in the rest of the poem.

\section{Vignette 2: The Hebrus River}

Following this metapoetic opening, the fragmentary lines of Ode 16 resurface next at the banks of the northern Hebrus River $\left(5^{-7}\right)$ :

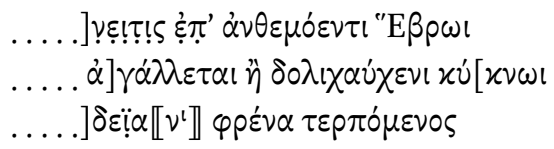

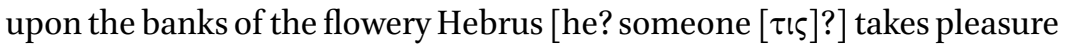
in ... or in the long-necked swan ... delighting his heart ...

For Maehler and others, these lines explicitly call to mind Alcaeus fr. $307 \mathrm{c}$. Alcaeus fr. 307c comes to us in the form of a prose summary by the fourthcentury CE rhetorician Himerius. Because this fragment has traditionally played a leading role in the interpretation of Ode 16, I quote it here in full (Alcaeus fr. 307c = Himerius Orations 48.10-11 [pp. 200-201 Colonna]):

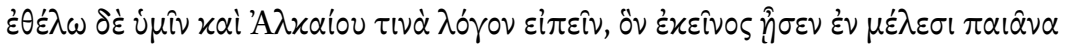

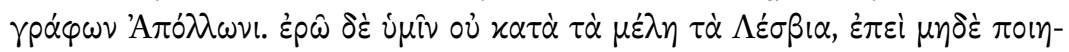

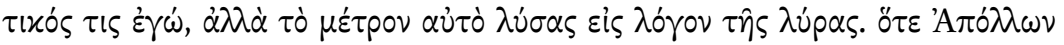

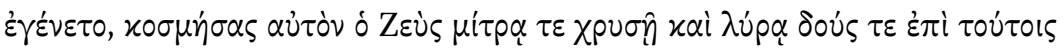

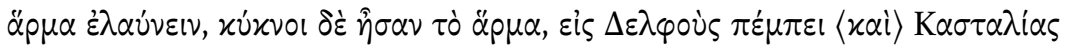

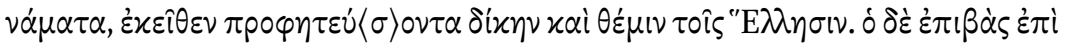

23 At another level, this epinician resonance may anticipate the poem's own encapsulation of Trachiniae and that poem's leveraging and subsequent complication of Heracles' status as an epinician hero. See Swift 2011 for how Trachiniae makes uses of epinician language as well as Heracles' traditional characterization in epinician for its own tragic ends. 


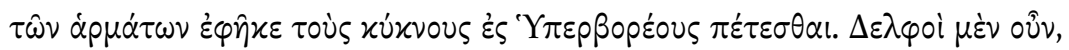

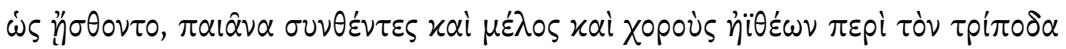

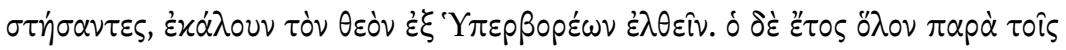

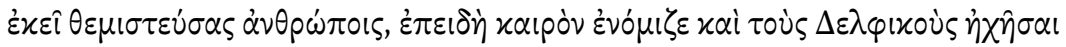

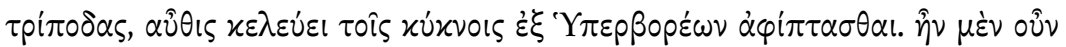

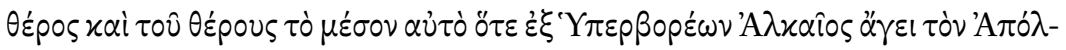

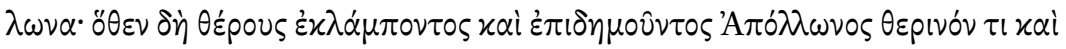

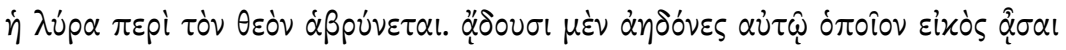

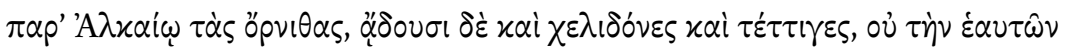

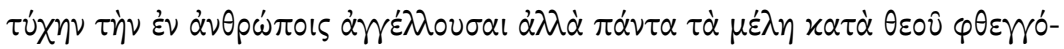

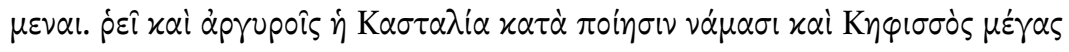

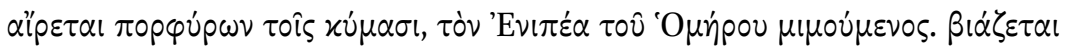

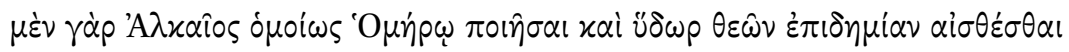

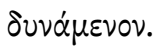

I wish to tell you a tale of Alcaeus, which he sang in lyric verse when he wrote a paean to Apollo; and I shall tell it not in the Lesbian verses, since I have nothing of the poet in me, but changing the actual metre of the lyre into prose. When Apollo was born, Zeus equipped him with golden headband and lyre and gave him also a chariot of swans to drive, and sent him to Delphi and the spring of Castalia, thence to declare justice and right for the Greeks; but when Apollo mounted the chariot he directed the swans to fly to the land of the Hyperboreans. Now when the Delphians learned this, they composed a paean and a tune and arranged dancing choirs of youths around the tripod and called on the god to come from the Hyperboreans. Apollo, however, delivered law among the men of that region for a full year; but when he thought it was time that the tripods of Delphi should ring out too, he ordered his swans to fly back again from the Hyperboreans. Now it was summer and indeed the very middle of summer when Alcaeus brings Apollo back from the Hyperboreans: so what with the blaze of summer and the presence of Apollo the poet's lyre also adopts a summer wantonness in the account of the god: nightingales sing for him the kind of song that one might expect birds to sing in Alcaeus, swallows too and cicadas, not proclaiming their own fortunes in the world but telling of the god in all their songs. Castalia flows in poetic fashion with waters of silver, and great Cephisus rises in flood, surging with his waves, in imitation of Homer's Enipeus: for Alcaeus is compelled just like Homer to give even water the power to sense the presence of gods.

Trans. D.A. CAMPBELL 
Alcaeus' account, as paraphrased by Himerius, encourages Maehler to reconstruct Ode 16's scene at the Hebrus River as a stopover for Apollo as the god travels south on his swan chariot from the Hyperboreans to Delphi. ${ }^{24}$ Even a cursory reading of Himerius' text, however, reveals several discrepancies between it and Ode 16. Himerius' paraphrase does not mention the Hebrus or, more generally, a sojourn of Apollo en route to Delphi. Ode 16, in turn, refers neither to the Hyperboreans nor to a swan chariot.

I note as well a more substantial issue. The long-accepted view that Apollo breaks his southward journey on the banks of the Hebrus in Ode 16 relies on taking the god as the subject of this vignette's main verb, $\dot{\alpha}] \gamma \dot{\alpha} \lambda \lambda \varepsilon \tau \alpha \mathrm{l}$ (6). Yet this reading is not secure. The first visible traces of the fragmentary line 5 seem to be

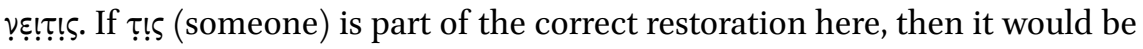
the subject of $\dot{\alpha}] \gamma \dot{\alpha} \lambda \lambda \varepsilon \tau \alpha$. This restoration causes problems for Maehler's image of Apollo at the Hebrus even as he takes $\tau \iota \zeta$ seriously as a possible option. As he

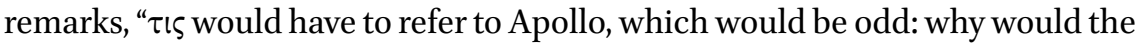
god not be named?"25 Rather than attempt to reconcile Apollo with $\tau \iota \varsigma$, however, we should instead consider the possibility that this "someone" refers to someone other than the god. In so doing, we might compare this $\tau i \varsigma$ to its other, frequent occurrences within the Bacchylidean corpus, including in Odes 3.21-

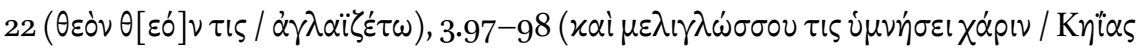

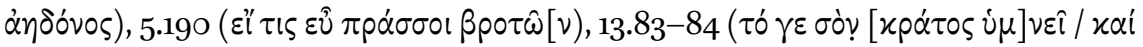

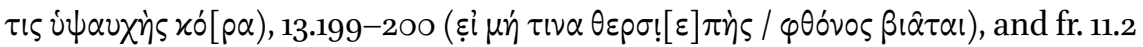

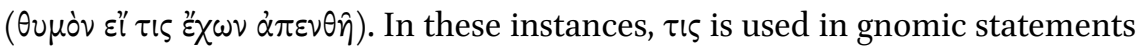
(as in Ode 5.19o and fr. 11.2, where the $\tau \iota \zeta$ is also preceded by $\varepsilon l$, as it seems to be in Ode 16) and is also found in contexts of celebratory singing (for example, Odes 3.97-98 and 13.83-84). It is conceivable that a generic "someone," and not Apollo, is the subject in these lines in Ode 16 and that the scene depicts a customary or habitual event. Although the $\tau \iota \varsigma$ does not seem to be singing himself in this passage, as he/she is in Odes 3 and 13, he is delighting in music: as we will soon see, this vignette's collocation of the swan and the Hebrus is evocative of song and is an image linked specifically to Apolline music.

For now, we cannot determine with any certainty the subject of this vignette.

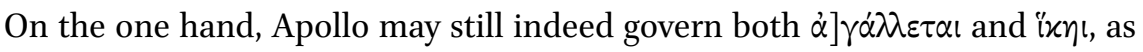
most editors assume. On the other, as the parallels discussed below demonstrate, swans and rivers do not require Apollo's physical presence in order to be paired together, and the subject who enjoys the swan's music may well be

24 Maehler 2004: 165-166. See also Calame 2013: 344 on these lines: "The god clearly breaks his journey [from the Hyperboreans to Delphi] to enjoy the melodious song of a swan."

25 Maehler 2004: 168. 
an unnamed $\tau \iota$ instead. ${ }^{26}$ We should, therefore, not assume that Apollo himself is at the Hebrus and accordingly use that assumption as a way of reconstructing the strophe's larger scenario of the god's return from the Hyperboreans.

I turn instead to two other possible parallels for this vignette. First, the undateable, brief Homeric Hymn to Apollo (21) offers a swan at another northern river, the Peneus $(21.1-5)$ :

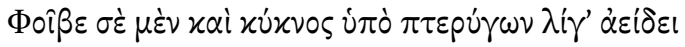

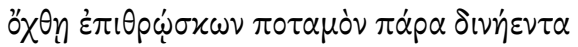

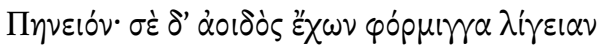

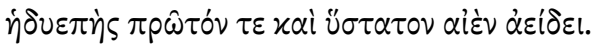

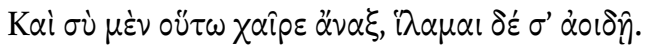

Phoebus, even the swan sings of you in a clear tone to the beating of its wings as he alights upon the bank beside the eddying Peneus River; and the sweet-speaking bard, holding his clear-toned lyre, always sings of you both first and last. So too, greetings, lord; I seek your blessing with my song.

Second, a choral ode in Aristophanes' Birds places swans on the banks of the Hebrus, the same river found in Ode 16 (769-784):

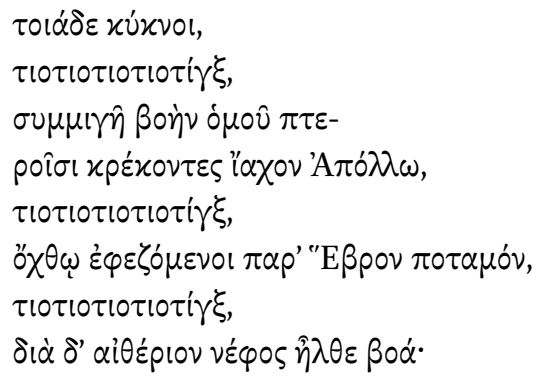

26 Understanding $\tau \iota \varsigma$ as the subject of $\dot{\alpha}] \gamma \dot{\alpha} \lambda \lambda \varepsilon \tau \alpha$ also eliminates the need to explain why Apollo is first referred to here in the third person and then, only two lines later, in the second person with 'ínı (8). A survey of Bacchylides' extant epinicia and dithyrambs suggests that such a shift from the third to second person is unparalleled, although editors pass over this discrepancy and thus must not view it as particularly abrupt. Ode 19.8-14 may be a rough analogue. Morphologically, ǐ $₹$ ı could also be a third person singular (present subjunctive, from i $i \omega$ ), although I find it more likely that this verb (with its attendant image of pursuing flowers of paeans) belongs with the vocative address to Pythian Apollo in the following line. 


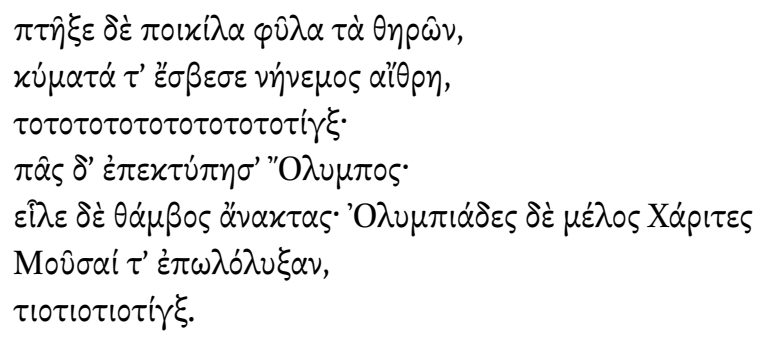

Just so did swanstio tio tio tio tinx!beating wings in unison raise a harmonious whoop for Apollotio tio tio tio tinx!gathered on the bank by Hebrus Rivertio tio tio tio tinx! their whooping pierced the cloud of heaven; the manifold tribes of beasts were cowed, and the cloudless clear air quenched the wavesto to to to to to to to to tinx!All Olympus reverberated, amazement seized its lords, and the Olympian Graces and Muses replied in cheerful songtio tio tio tio tinx!

Trans. J. HENDERSON

In both passages, we encounter swan(s) honoring Apollo through the sound created by their wings alighting on a river bank. The quality of these sounds is characterized in both passages as musical: in the Homeric hymn, the swan's wings are linked to its ability to sing ( $\dot{\alpha} \varepsilon \dot{\delta} \delta \varepsilon ı)$ while, with greater detail, Aristo-

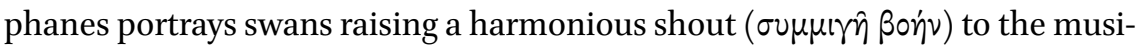

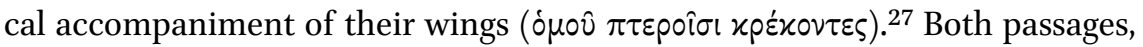
then, foreground the river bank not because it is a resting place for a southbound Apollo but because it is a place that generates a particular kind of music for the god through the sound of swans alighting upon it. It is also worth noting that these passages both juxtapose swan music to another form of singing

27 For $\sigma u \mu \mu \imath \gamma \hat{\eta}$ having the musical resonance of "harmonious," see Dunbar 2002: 322; for the

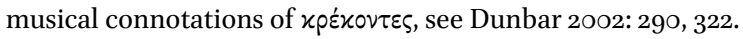


performed by another kind of singer. Thus, in the Homeric hymn's paratactic sequence, we are told that the swan sings for Apollo ( $\dot{\varepsilon \varepsilon i \delta \varepsilon \varepsilon, ~ 1), ~ a n d ~ t h e ~ b a r d ~}$ sings for him as well ( $\dot{\varepsilon} \varepsilon \dot{\delta} \delta \varepsilon l, 4)$. In Birds, the Muses and Graces on Olympus raise a song of joy in response ( $\mu \varepsilon^{\prime} \lambda \circ \varsigma_{\text {... }} \dot{\varepsilon} \pi \omega \lambda \hat{o}^{\lambda} \nu \xi \alpha \nu,{ }^{782-783)}$ ) to the swans' own musical outburst for Apollo.

In light of these juxtapositions, I note that Alcaeus fr. 307c itself presents a similar string of discrete but comparable forms of singing. This feature of the fragment is typically overlooked in favor of tracking the course of Apollo's own travels within the passage. Yet, in Himerius' paraphrase, Alcaeus' closing image includes assorted creatures performing in honor of the god's return from the Hyperboreans: "Nightingales sing for him the kind of song that one might expect birds to sing in Alcaeus, swallows too and cicadas, not proclaiming their own fortunes in the world but telling of the gods in all their songs." ${ }^{28}$

A passage from Plutarch conforms to this pattern as well. In connecting swans to Apollo, Plutarch lists their singing as one of the various types of musi-

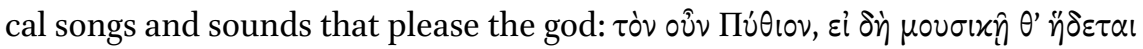

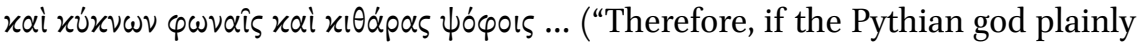
finds pleasure in music and the songs of swans and the sound of lyres ...," Mor. $387 \mathrm{c}$ ). These instances, then, all suggest that the music made by swans can occur as part of a larger motif that presents a pairing or sequence of different Apolline forms of music-making.

To return to Ode 16, it is not likely that the poem's reference to the swan and the Hebrus depict a resting place at the river as Apollo returns from the Hyperboreans, a reconstructed mythic scenario lacking extant parallels. ${ }^{29}$ Rather, the swan and the river seem to signal the poem's interest in the kind of music swans are known to make upon river banks in Apollo's honor, a connection for which parallels do exist. We are further encouraged to understand the swan in Ode 16 as a reference to swan music if we accept Maehler's restorations for the beginning of line 7 . On the papyrus, the last letter of the first visible word in the line, $\nu$, was crossed out and replaced by a superscript iota $\left.(\ldots ..] \delta \varepsilon \ddot{i} \alpha \llbracket \nu^{\imath} \rrbracket\right)$. Maehler suggests that the letters ï $\alpha$ of this cluster thus represent $\hat{i} \alpha$ (voice) and connects the word to the swan in the line above. In addition, he proposes $\mu \varepsilon \lambda \mid \alpha] \delta \varepsilon\langle\hat{\langle}\rangle$ (honey-sweet) for the preceding lacuna, citing a number of other

28 See also Pl. Phd. $84 \mathrm{e}-85 \mathrm{~b}$, in which the singing of swans is mentioned in relation to a series of other birds' singing (that of the nightingale, swallow, and hoopoe) and swan song is again connected to Apollo.

29 Alcaeus fr. 43 does mention the Hebrus River but in a completely different context and one that does not mention Apollo: it relates instead the course of the river and describes it as a place where young women bathe. 
parallels for the mellifluous singing of swans. ${ }^{30}$ If Maehler is correct, such a restoration would form another connection with both the Homeric hymn and the Birds passages. In both of these passages, the sound of swan wings on the river bank form the accompaniment to the swans' own cries or singing. In Ode 16 , we might have a similar collocation of the swan's voice ( $(\hat{\alpha} \hat{\imath})$ and the music of their alighting upon the Hebrus.

Second, I would suggest that the motif of presenting pairs or larger sequences of songs for Apollo found in the examples above seems to occur in Ode 16 as well. For Bacchylides clearly contrasts the swan in line 6 to another

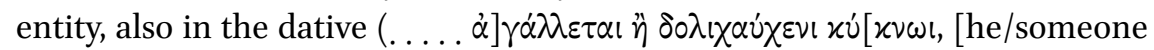
delights in ... or in the long-necked swan ..., 6]). To fill the lacuna, Maehler offers $\mu \circ \sigma_{\sigma \alpha l}$ (muse) and $\mu \circ \lambda \pi \hat{\alpha} \mathrm{l}$ (song) as possible restorations. ${ }^{31}$ These suggestions are intriguing because either possibility would bolster what appears to be the overarching import of these lines, namely, their concern with music or, more specifically, with the juxtaposition of different types of music.

I have proposed in this section that the vignette comprising lines $5^{-7}$ does not in fact depict a scene from the myth of Apollo and the Hyperboreans or model itself on the version of the myth found in Alcaeus fr. 307c. Rather, I would argue that these lines, however fragmentary, reveal themselves to be one instantiation of a widespread motif that links swan music to other forms of singing in honor of Apollo by other discrete types of singers. Put another way, Ode 16 partakes in a larger cultural tendency to present Apollo as a god who inspires instances of polyphony by rousing a veritable cosmos of diverse singers (insects, swans, bards, the Muses themselves) to delight him with their own distinctive music.

\section{Vignette 3: Delphi}

With this conclusion in mind, let us turn to the final vignette of the strophe as well as to the opening line of the antistrophe that moves the poem into its mythic narrative. Before considering the interpretation of these lines, it is worth reviewing Maehler's analyses of this portion of the poem since they best represent a generally accepted approach to this problematic and lacunose passage. As we will see, the established approach to the strophe's ending and the beginning of the antistrophe has far-reaching implications for our sense of Ode 16 as a whole and, more broadly still, for our understanding of the relationship between ancient categories of genre.

$30 \quad$ According to Maehler (2004: 168), since diaeresis frequently occurs over intial iota in this papyrus, the $\ddot{i}$ (in ..... $\left.] \delta \varepsilon \ddot{\alpha} \alpha \llbracket \nu^{\imath} \rrbracket\right)$ could well be the beginning of a new word.

31 On the lacuna of line 6, Maehler (2004: 168) notes, "a dative seems likely in the gap." 
The two primary issues within this portion are the opening lacuna of line 8 and the meaning of $\tau \dot{\sigma} \sigma \alpha$ in line $11(8-13)$ :

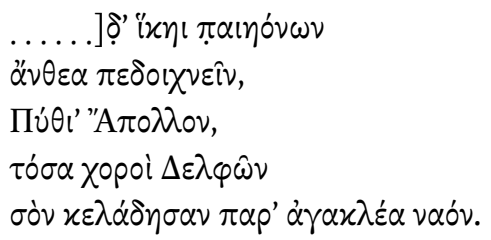

$\pi p^{\prime} \nu \gamma \varepsilon x \lambda \varepsilon \dot{\sigma} \mu \mu \varepsilon \nu \lambda เ \pi \varepsilon i \nu$

... you come to pursue flowers of paeans, Pythian Apollo, as many as the choruses of Delphians are accustomed to sing beside your far-famed temple. But, first, we sing [how the son of Amphitryon] left [Oechalia] ...

Maehler's own translation of this stretch of lines is again linked to his view of the strophe's close kinship with Alcaeus fr. 307c. First, following Paul Maas, Maehler argues that only two syllables are required in the lacuna of line 8 and

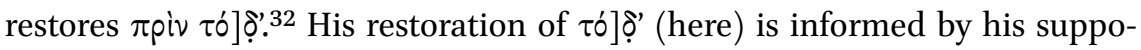
sition that the present poem was performed at Delphi as the Delphians await Apollo's return from the Hyperboreans. Maehler's translation of lines 8-10 thus reads "until you come here, Pythian Apollo, to go after flowers of paeans."33

Second, Maehler takes $\tau \dot{\sigma} \sigma \alpha$ as a demonstrative pronoun and accordingly translates the subordinate clause as "these things (or 'this much') ( $\tau \dot{\sigma} \sigma \alpha)$ the

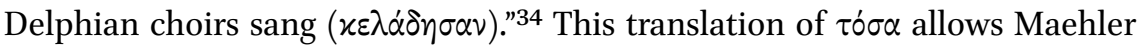
to interpret the preceding lines of the strophe as a quotation of what was sung and, drawing on the paradigmatic Alcaeus fragment, to suggest that the entire strophe can be characterized as a kind of cletic hymn performed by the Delphians to recall Apollo from the Hyperboreans. ${ }^{35}$ The Alcaeus passage does mention that the Delphians composed a paean and a song and set up choruses for the absent Apollo. Yet it is unclear from Himerius' summary whether

32 Maas 1921: 23 n. 2. As Maehler (2004: 168) notes, this use of $\pi$ piv paired with ixn would be in keeping with other uses of $\pi$ pi $v$ with the subjunctive (without $\alpha \nu$ ) that denote an anticipated or recurring event.

33 Maehler 2004: 168.

34 Maehler 2004: 169. He cites several parallels in which this demonstrative pronoun follows a direct speech. See also Uhlig 2017, who discusses this passage as an example of oratio recta and connects this feature to the poem's own conceptualization of reperformance.

35 As Maehler (2004: 169) concludes, the strophe is "rather similar to Alcaeus' hymn." See also Maehler 2004: 164-165. Cf. the similar assessment by Burnett 1985: 193 n. 14. 
the Alcaeus fragment was itself considered a cletic hymn, as Maehler seems to assume. If it were a cletic hymn, it would present itself as a strangely ineffective version of one, since part of the point of mentioning the Delphians' singing in the passage seems to be to highlight its inadequacy at attracting the god's attention: in the summary, Apollo appears to ignore the Delphians when, following the Delphians' choral solicitations, he decides to remain among the Hyperboreans for an entire year instead of heading straightaway to Delphi. That is to say, the Alcaeus fragment once again seems not to correspond with what is taking place in Ode 16.

We are on firmer ground, at least in terms of the state of the papyrus, when we move from the strophe to the antistrophe. The end of the strophe is followed by a strong break, marked by the antistrophe's opening $\pi p^{\prime} \nu \gamma \varepsilon x \lambda \varepsilon \dot{\varepsilon} \mu \varepsilon \varepsilon v$. This use of $\pi$ i iv seems best taken as an adverb and Maehler translates the phrase as "beforehand, we tell ..." ${ }^{36}$ This phrase initiates the extended mythic narrative of the antistrophe and epode.

Maehler's analysis of the transition between the strophe and antistrophe again exemplifies the traditional line of interpretation. His analysis relies on connecting the mythic scenario of Alcaeus fr. 307c to a passage from Plutarch referred to briefly above (Mor. 389c). In Plutarch's passage, the Delphians cease from singing paeans during the three winter months when Apollo is absent and instead sing dithyrambs for Dionysus. According to Maehler's argument, since the strophe, like the Alcaeus fragment, envisions Apollo returning from the Hyperboreans, the antistrophe and epode consequently cast themselves as a performance taking place in the interim at Delphi. Enlisting Plutarch's assertion that the Delphians honor Dionysus with dithyrambs while Apollo is away, Maehler concludes, "If, as seems likely, this statement reflects fifthcentury practice, $\mathrm{B}$ [acchylides'] ode could well be such a dithyramb, performed at Delphi during the winter months before Apollo's return."37 While Maehler goes further than most scholars in his careful efforts to excavate Ode 16's ritual occasion, I emphasize again that there is seemingly universal acceptance that

36 See Maehler 1997: 16o-161 and 2004: 169, where he presents his justification for taking $\pi p^{i} v$ as an adverb instead of a conjunction and also makes the case for understanding $x \lambda \varepsilon_{\varepsilon} \rho \mu \varepsilon v$ as a present indictive instead of an imperfect (i.e., $\left.\pi \rho^{\prime} \nu \gamma^{\prime} \varepsilon^{\prime} \chi \lambda \varepsilon \dot{\varepsilon} \rho \mu \varepsilon \nu\right)$.

37 Maehler 2004: 165. In light of this conclusion, Maehler (1997: 150) proposes a possible ritual occasion: he tentatively suggests the performance context of the Delphic Theoxeny, which celebrated Apollo, Leto, and Dionysus together, as the original occasion for Ode 16. If, as he speculates, the Theoxeny began before Apollo's return and culminated in his epiphany (although there is no evidence for this scenario), Ode 16 could have been performed at the beginning of the Theoxeny before the god's return. This scenario is picked up and more forcefully asserted by Calame 2013: 344 . 
the poem was performed at Delphi. ${ }^{38}$ This acceptance extends to the restoration of the poem's title as EI $\Sigma \mathrm{E} \Lambda \Phi O Y \Sigma$ (For Delphi), albeit in brackets, in the major editions of Bacchylides, including the Budé, Loeb, and Teubner.

In short, the traditional interpretation, exemplified by Maehler but articulated by numerous scholars, can be summarized as follows: Ode 16 was performed at Delphi by a chorus awaiting Apollo's return from the Hyperboreans, a return solicited by the strophe's invocation. This reconstruction, in turn, elicits a particular understanding of the poem's genre(s): following the strophe's explicit reference to Apollo's genre of the paean, the poem then shifts generically to the dithyrambic mythic narrative of the antistrophe and epode and, in so doing, implicitly honors Dionysus, the god in residence at Delphi during the present performance.

Before offering an alternative reading, I would like to identify several interrelated problems with this reconstruction. First, this argument relies heavily on both the Alcaeus and Plutarch passages to reconstruct the original performance context of Ode 16 and, in so doing, necessarily views them as complementary texts. We have already found that the Alcaeus fragment in and of itself poses problems as a paradigm for Ode 16. But I note here a further issue, namely, that Alcaeus and Plutarch are not telling quite the same myth. Alcaeus' myth emphasizes Apollo's initial avoidance of Delphi in favor of the Hyperboreans and asserts that, after a year among the Hyperboreans, his eventual arrival to Delphi took place in mid-summer. By contrast, Plutarch's anecdote concerns Apollo's annual return from the Hyperboreans and places this yearly event at the end of winter. Alcaeus and Plutarch deploy Apollo's connection to the Hyperboreans for different aetiological ends. Accordingly, their joint explanatory power for illuminating Ode 16 should be questioned.

Second, this reconstructed context produces an internal temporal disjunction or incoherence between the strophe's $\tau \dot{\sigma} \sigma \alpha . . . \kappa \varepsilon \lambda \alpha^{\prime} \delta \eta \sigma \alpha \nu$ (these things ... they sang, 11-12) and the antistrophe's opening $\pi \rho i \nu \gamma \varepsilon x \lambda \varepsilon$ \&́ $\mu \varepsilon \nu$ (beforehand, we tell, 13). For it is not clear how something taking place in present time ("beforehand, we (now) tell") could occur before something that has happened in the past ("these things the Delphians sang"). The phrase "beforehand, we tell" does make logical sense in relation to the invocation to Apollo, and a paraphrase of that progression would be "until Apollo comes, we (now) tell (this mythic narrative)." But to privilege this progression is to ignore the intervening $\tau$ ó $\sigma \alpha$ clause

38 Pfeijffer's (1999a: 55) comment is representative: "The fact that this ode was performed at Delphi with all probability ..." See also Burnett (1985: 193 n. 14): "The place [of the performance] must be Delphi ...”; Fearn (2007: 237): “In the case of Bacchylides 16, the poem's opening points us to a Dionysiac festival context at Delphi ...” 
that, following Maehler's translation, places the cletic address to Apollo in past time. Maehler's proposed sequence strains or obscures the temporal relationship between the strophe and the antistrophe-epode. ${ }^{39}$

Third and more importantly, this reconstruction rests on an understanding of generic categories as clear-cut and mutually exclusive, with genres neatly mapped onto their respective gods. Because the strophe mentions paeans and Apollo and because, it is argued, Apollo is absent from Delphi for the present performance, the antistrophe and epode must necessarily be a dithyramb in honor of Dionysus. ${ }^{40}$

Finally, and in conjunction with this third concern, it is not evident how the antistrophe and epode's mythic narrative relates to a Delphic context. As we will see in Part II, scholars have demonstrated that this portion of the poem presents a version of the myth of Heracles and Deianeira that closely corresponds to, even depends upon, Sophocles' Trachiniae. The standard interpretation of Ode 16, which places the poem at Delphi, cannot account for this relationship between Ode 16 and Trachiniae beyond pointing to a loose association between the poem's tragic material and Dionysus' purported presence at Delphi during the poem's original performance. ${ }^{41}$ Yet, this vague Dionysiac connection does not satisfactorily address Bacchylides' citation of Sophocles' idiosyncratic tragic version of a myth or, more generally, why he would wish for this particular lyric poem to interact so closely with the genre of tragedy.

How else, then, can we view the relationship between the strophe and antistrophe-epode in a way that attends to these related concerns, especially those of genre and performance context? I suggest that the conclusions reached in the previous section offer a means of addressing them. For it is possible to extend the vision of Apolline polyphony encountered there to the remainder of the poem as well. Ode 16 as a whole appears to be structured as a sequence of different musical performances in honor of Apollo. In order to track this sequence within Ode 16 , however, it is necessary to modify slightly Maehler's translation of lines $8-13$ by recuperating two observations made long ago by Richard Jebb. First, Jebb takes $\tau o ́ \sigma \alpha$ not as a demonstrative pronoun but instead

39 Maehler (1997: 16o-161) himself considers the various possibilities for the temporal rela-

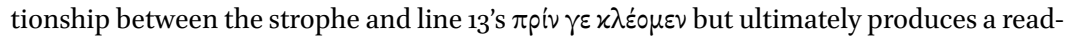
ing that focuses on the relationship between Apollo's arrival and what the chorus is now singing and, in so doing, seems to ignore the intervening $\tau$ có $\alpha$ clause. contrast between paeans and dithyrambs in the fifth century."

41 Thus Rutherford (1994-1995: 118) points to this poem as an example of how the "implied Dionysiac context of the genre [of dithyramb] accommodates the uses of the 'themes of transgression and disaster." 


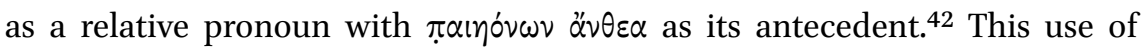
the relative without a correlating demonstrative pronoun is rare, but, as Jebb observes, Bacchylides uses the same construction in Ode $1\left(1.145^{-148}\right):^{43}$

$$
\begin{aligned}
& \ldots \pi] \alpha \tau \rho i \omega \nu \\
& \left.\tau^{\prime} \text { oง่x [.].].[-- }-x\right] \alpha \lambda \omega \hat{\omega} \nu \text {, }
\end{aligned}
$$

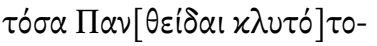

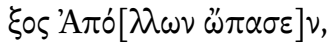

$$
\begin{aligned}
& \text {... his father's fine achievements, all those which the famous archer Apollo } \\
& \text { granted to Pantheides ... }
\end{aligned}
$$

Second, Jebb maintains that $\chi \varepsilon \lambda \alpha \dot{\delta} \eta \sigma \alpha \nu$ (12), the verb within the relative clause, must be a gnomic aorist. ${ }^{44}$ I note that the force of the gnomic aorist, which emphasizes the customary nature of $x \varepsilon \lambda \alpha \dot{\delta} \eta \sigma \alpha \nu$, would correspond well to Maehler's restoration of $\pi$ pí $v$ with the subjunctive to denote a habitual occurrence in the opening lacuna of line $8 .{ }^{45}$

Incorporating Jebb's interpretations, then, I translate lines 8-13 as follows: ${ }^{46}$ "[before] (as you habitually do) you come to pursue flowers of paeans, Pythian Apollo, as many paeans as the choruses of Delphians are accustomed to sing around your famous temple, before (you do that), we now tell how ..." Taking $\chi \varepsilon \lambda \alpha \dot{\delta} \eta \sigma \alpha \nu$ as a gnomic aorist relieves the temporal discordance between

\footnotetext{
42 Jebb 1905: 371.

43 See Jebb 1905: 246-247 (N.B., in Jebb's edition of Ode 1, line 147 = line 37). See also Maehler 1982: 19 on Ode 1.147. Maehler (1997: 159-16o) also considers the possibility that $\tau$ ó $\sigma \alpha$ is a relative pronoun but, in the end, favors taking it as a demonstrative.

44 Maehler raises this possibility in his 1997 commentary but the translation in his 2004 edition suggests that he does not ultimately interpret it as such.

45 See above n. 32 . This use of the subjective $+\pi$ piv occurs without $\alpha$ $v$. Further, as noted above, if we read $\tau$ ı at line 5 in the second vignette and take it to refer to a general, customary action, then the second vignette corresponds to the third in presenting another habitual action related to Apolline music.

46 Jebb (1905: 371) like Maehler takes $\pi$ piv in line 13 as adverbial. In the opening lacuna of

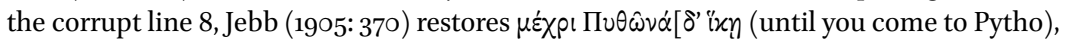
with the supposition that five syllables should fit the textual gap. I remain agnostic about the number of syllables that belong in this lacuna, although for my own interpretation

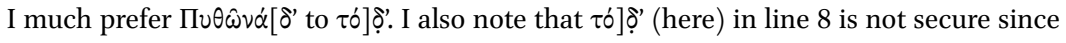
Maehler places a dot under the delta, the one letter of this word that he does not restore. Nevertheless, I would emphasize that Maehler and Jebb, despite their differences over the length of the lacuna, both agree that a temporal conjunction belongs in the gap.
} 
the end of the strophe and the beginning of the antistrophe that was observed above for Maehler's scenario. Moreover, this translation emphasizes the inseparable link between the singing of paeans by choruses and the site of Delphi. ${ }^{47}$ Because of the lacuna, we cannot be certain of the location to which Apollo is being called in the invocation at line 8 ("before you come ..."). What is apparent, however, is the form of music Apollo can expect to find in his honor at Delphi. As the subordinate clause declares, the paean is the song for Apollo there, a category of song whose habitual, predictable performance around Apollo's Delphic temple the gnomic aorist underscores.

With the aid of Jebb's interpretation, the final image in the strophe can be read against the preceding cluster of song type-singer-locations in lines $5^{-7}$. A sequence now materializes in the poem's movement from the music made by swans at the Hebrus River to paeans sung by choruses at Delphi. In other words, in this progression, the strophe offers another instance of the motif of juxtaposing different forms of singing in honor of Apollo. Crucially, in Ode 16's own permutation of this pattern, each shift in song type and singer is accompanied by a corresponding shift in geographical location.

With this permutation in mind, I suggest that Ode 16 then continues this Apolline motif with the opening of the antistrophe, where the poem undergoes yet another shift on all three fronts. As the antistrophe begins, the poem restarts not only by introducing another kind of song performed by other singers but also by conjuring a new physical space. Thus we move from a reference to paeans to a mythic narrative of Heracles and Deianeira, from a reference to a chorus of Delphians to the first-person plural $\chi \lambda \varepsilon^{\prime} \circ \mu \varepsilon v$. And, at the same time, we move, in an attendant shift in location, from a reference to Delphi to the site of the present performance. For here I would revive an old conjecture that the performance of Ode 16 originally took place not at Delphi but at Athens. ${ }^{48}$

In Part II, I will address in greater detail the evidence for Athens as the site of the poem's performance and propose a specific Athenian ritual occasion. But, for now, taking Athens as the location of the chorus presently singing ( $\chi \lambda \varepsilon_{\varepsilon}$ $\mu \varepsilon v)$, we might note that the motif of sequencing songs for Apollo in Ode 16 assumes the shape of an ascending tricolon: first, the music of swans at the Hebrus; second, paeans by choruses at Delphi; finally and most elaborately, a mythic narrative comprising the antistrophe and epode by a chorus at Athens. Accordingly, an expanded translation of lines 8-13 might read: "[before] (as you habitually do) you come to pursue flowers of paeans, Pythian Apollo, as

47 It is worth noting that this argument still holds even if $\tau \dot{\sigma} \sigma \alpha$ is taken as a demonstrative.

48 The possibility of Athens as the site of Ode 16's performance was first suggested by Kamerbeek 1959: 6. See also March 1987: 63 n. 65; Maehler 2004: 165, 17 . 
many paeans as the choruses of Delphians are accustomed to sing around your famous temple, before (you do that), we (here in Athens) now sing (for you) how ..." As this translation underscores, viewing the entirety of Ode 16 as a song in honor of Apollo frees us from trying to excavate a discernible connection between the antistrophe-epode and Dionysus.

These observations yield several related ones in turn. In the case of the culminating element of the tricolon, the poem ceases simply to identify or name different types of Apolline song as it does in the strophe and instead becomes a type of song, as it opens up into the mythic narrative for the remainder of the poem. Put another way, the strophe functions as a kind of priamel to the antistrophe-epode, presenting a list of different song types as the lead-up to the actual song the chorus will now sing. ${ }^{49}$ Further, following their shared cultic origin on Pieria, Ode 16's sequence of individual songs moves from the Hebrus in Thrace, to Delphi, to Athens. This geographical progression implies that place is profoundly connected to, even the determining factor for, the type of song performed at each of the locations in the poem. Since the different songs presented within Ode 16 are all in honor of Apollo, the poem seems to imply that the god himself does not entirely govern the type of music that will be sung for him as much as the physical environment and its inhabitants do. The importance accorded to physical space and community has implications for Ode 16's conceptualization of genre, as we will see in Part I's discussion of Athens as the site of the poem's performance. Before turning to Part II, it is worth observing how this sequence of songs relates both to the antistrophe and epode's mythic narrative and to the poem's opening metapoetic frame.

The autonomy of song as an operating principle within Ode 16 appears to inform the correlation between the antistrophe and epode. For, despite jointly comprising a unified mythic narrative, the two stanzas nevertheless operate independently of one another in at least one important respect, namely, their focalization. At first glance, it is curious that in a mythic narrative of such "extreme brevity" and with so much mythic ground to cover (Heracles's preparations for a sacrifice at Cenaeum, Deianeira's learning of Iole, and the centaur Nessus' fateful gift) Bacchylides devotes the antistrophe to cataloguing preparations for a sacrifice that will never occur. The antistrophe enters its myth at the point at which Heracles is apportioning sacrificial victims to Zeus, Poseidon, and Athena, unaware of his own impending immolation (13-22):50

49 See the discussion in this volume's introduction of Pindar fr. 128c SM as another priamel that presents a series of distinct kinds of song.

50

Quotation from Platter 1994: 338. 


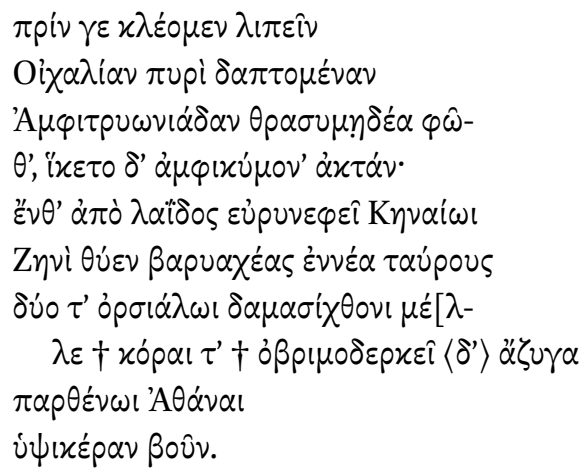

But, first, we sing how the son of Amphitryon, the bold-planning mortal, left Oechalia devoured by fire and arrived at the promontory washed by waves; there from his spoils he was about to sacrifice nine deep-bellowing bulls to Zeus of Cenaeum, lord of spreading clouds, and two to the searouser and earth-shaker, and a high-horned cow, unyoked, to the maiden Athena with the mighty glance.

With these ornate enumerations of animals and gods, the antistrophe is seemingly unaware that this sacrifice will never occur and that its relevance will soon be superseded by the revelation of Heracles as the actual sacrifice. But if we understand the antistrophe as focalized through Heracles, then the care allotted to these futile preparations makes greater sense. As the passage's focalizer, Heracles is, as it were, flaunting or parading these sacrificial victims from his own private store $(\dot{\alpha} \pi \dot{\partial} \lambda \alpha i \ddot{\delta} \circ \varsigma, 17) .{ }^{51}$

In the shift from antistrophe to epode, however, we move from Heracles' "external action" to Deianeira's "internal realm of intellect and emotion," as Anne Pippin Burnett has observed. ${ }^{52}$ Accompanying this shift is a commensurate shift in focalization: the epode does not simply narrate Deianeira's emotional and intellectual experience as she learns that her husband is sending home a new wife but is also focalized through her experience. The transition between the antistrophe and epode crystalizes this shift in focalization

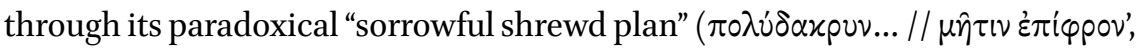

$5^{1}$ And we might note the trick of the grammar with $\theta$ vi (18): we initially assume that Heracles is actually making all of these sacrifices (taking $\theta \dot{v} \varepsilon v$ as an unaugmented imperfect indicative ["he was sacrificing"]) until, upon reaching the delayed $\mu \varepsilon \hat{\varepsilon}[\lambda] \lambda \varepsilon$ in the following line, we double back and reinterpret it as a Doric infinitive. Heracles is only "about to sacrifice" all of these victims. I owe this observation to Leslie Kurke. 
$24-25){ }^{53}$ The phrase bridges the two stanzas with the first adjective $\pi 0 \lambda v^{-}$ $\delta \alpha x p u v$ left dangling in the antistrophe until its noun, $\mu \hat{\eta} \tau \imath$, appears in the epode. Following the appearance of $\mu \hat{\tau} \tau \imath$, however, we encounter the plan's second defining term, $\dot{\varepsilon} \pi i \varphi \rho o v$ '. The resulting phrase, straddling the strophe break, begins as "sorrowful" in Heracles' antistrophe before transforming into something "shrewd" in Deianeira's epode. That is, while his wife's plan will be sorrowful for Heracles at Cenaeum, in her own epode, Deianeira, still ignorant of her plan's fatal consequences, perceives it as a resourceful response to the news of Iole. What is more, this news of Iole, as it is summarized in the epode $\left(25^{-29}\right)$, also seems filtered through Deianeira's perspective since it is characterized as "distressing" ( $\tau \alpha \lambda \alpha \pi \varepsilon v \theta \varepsilon \dot{\varepsilon} \alpha, 26) .{ }^{54}$

Thus, just as the strophe offers vignettes of discrete songs by discrete singers, the antistrophe and epode, though comprising a shared song, simultaneously display a degree of cognitive dissonance between their respective protagonists. ${ }^{55}$ Further, like the strophe's vignettes, Heracles in his antistrophe and Deianeira in her epode occupy separate geographical spaces, with Heracles at Cenaeum and Deianeira, it can be assumed, at Trachis. A temporal disjunction also obtains between them, with Heracles' antistrophe focused on the future $\left(\mu \varepsilon^{\prime}[\lambda] \lambda \varepsilon, 19-20\right)$ and Deianeira's epode moving backwards in time from present to past events. ${ }^{56}$ The antistrophe and epode may share a mythic narrative, the

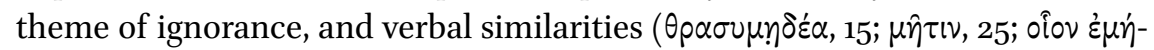
$\sigma \alpha \tau[0,30)$, and yet each stanza also maintains in part its own integrity and autonomy. Ode 16 is a poem in which not only its individual songs (those at the Hebrus, Delphi, and Athens) but also its structural parts (strophe, antistrophe, and epode) are entangled with but also somehow impermeable to one another.

To return to the image with which this section began, we are now in a posi-

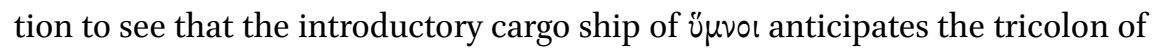
songs that emerges as the poem subsequently moves to the Hebrus, then to Delphi, and on to Athens. For, like these opening autonomous ü $\mu$ vol, the songs within the poem's sequence of physical settings are cast as distinct from one another, even as they share a divine point of departure on Pieria, the impulse to honor Apollo, and the space of Ode $16 .{ }^{57}$ We might even think of the poem

\footnotetext{
53 My thanks to Leslie Kurke for this point.

54 See also Pfeijffer (1999a: 54 ).

55 Platter (1994: 339) refers to Heracles and Deianeira in this poem as “independent actors."

56 I owe these last two points to Naomi Weiss.

57 The discrete parts of the poem are connected in other ways as well, including through recurring imagery: note that the banks of the flowery Hebrus (5) and the banks of the rosy Lycormas (34) bookend the poem.
} 
itself as a kind of metaphorical cargo ship freighted with $\check{\mu} \mu \nu$ o, each one bound for its proper geographical destination. In this way, the metapoetic frame anticipates well the model of song at work in the rest of the poem.

\section{Part II: Athens}

In the previous section, I proposed that we resuscitate an older argument that Ode 16 was first performed in Athens. I will lay out the case for this option in greater detail now. A performance context in Athens will clarify the poem's own capacity for generic flexibility as well as its relationship to the genre of tragedy.

Scholars often note that Bacchylides seems to have enjoyed a greater rapport with Athens than Pindar, especially in the case of his Dithyrambs..$^{58}$ Ode 16 itself exhibits an extensive connection to Sophocles' Trachiniae. And yet, Ode 16 has always been treated as an outlier to Bacchylides' Athenian Dithyrambs because of a pervasive scholarly conviction that it was performed at Delphi. This is not to suggest that a Delphic audience could not be familiar with a Sophoclean tragedy. Nevertheless, Bacchylides' and Ode 16's own close association with Athens encourages us to look for a suitable ritual occasion there for the poem's original performance.

\section{The Thargelia at Athens}

I will pursue the possibility that Ode 16 was performed in Athens by suggesting a specific Athenian ritual occasion that would accommodate such a performance: the Thargelia. The Athenian Thargelia was an annual spring festival that took place over two days during the month of Thargelion. ${ }^{59}$ The first day included a scapegoat ritual involving the expulsion of pharmakoi. On the second day, a procession carried a stew of first fruits in a vessel called the thargelos through the purified city. ${ }^{60}$ The destination of this procession was the sanctuary of Apollo Pythios, located to the southeast of the Acropolis, beyond the city walls, on the banks of the Ilissos River. Following the procession, the Athenians held choral performances, the festival's main attraction and sole competitive event. During the classical period, these contests featured five choruses of boys and five of men, a smaller-scale counterpart to the choral competitions of the

$5^{8}$ See, e.g., Fearn 2007: 234-241 and Calame 2013: $35^{\circ}$.

59 For discussions of the Thargelia, see especially Wilson 2000: 32-34 and 2007.

6o For the "ritual logic" underpinning these two distinct days of the festival, see Wilson 2007: 152, following Parker 1983: 25 . 
Great Dionysia held two months before. ${ }^{61}$ Epigraphic and literary evidence

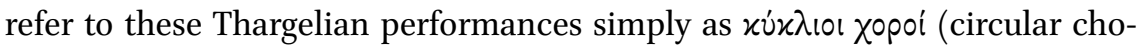
ruses). ${ }^{62}$ I will return to this designation while considering questions of genre below.

Both the cult of Apollo Pythios and its festival were of great antiquity in Athens and appear to date back as far as the eighth century. ${ }^{63}$ In the sixth century, the elder Peisistratus erected the first temple in the sanctuary known as the Pythion, while his grandson, the younger Peisistratus, dedicated an altar, described by Thucydides, whose find-spot has helped to identify the approximate location of the sanctuary. ${ }^{64} \mathrm{~A}$ choregic dedication reveals that the choral contests were well underway by the mid-fifth century, and Peter Wilson notes a general increase in activity for the cult at this time. ${ }^{65}$ I propose that this festival of the Athenian Thargelia occasioned the first performance of Ode 16, not long before the mid-fifth century, when both the cult and its annual festival were in full swing. This proposal frees us from trying to excavate a meaningful connection between the poem and Delphi: we are no longer tied to Delphi, for instance, in order to make sense of the invocation to Pythian Apollo at line 10, since this address is equally at home at the Thargelia with its cult of Apollo Pythios. In this context, it is also tempting to relate the prominence of river banks in Ode 16 ("upon the flowery Hebrus" [5] and "upon the rosy Lycormas" [34]) to the Pythion's setting on the banks of the Ilissos. ${ }^{66}$

We cannot ascribe any extant song with certainty to the Thargelia, but scholars have long contended that Bacchylides' Ode 18 was originally performed

61 Wilson 2007: 151. Although the scapegoat ritual has monopolized modern scholarship on the Thargelia, Parker (1996: 95), followed by Wilson (2000: 32-33), asserts that it was the choral competitions that would have been a fifth-century Athenian's primary association with the Thargelia.

62 Wilson 2000: 33; Fearn 2007: 235 .

63 Wilson 2007: 153 .

64 Thuc. 6.54.6 and Wilson 2007:153-154. The Peisistratids' interest in establishing a cult of Apollo Pythios at Athens may have been due to their fraught relationship with Delphi (Wilson 2007: 153). The prize for the choral competitions was a tripod, and Wilson (2000: 16) makes the intriguing suggestion that the Thargelia, given its link to Delphi through the cult of Pythian Apollo, was the first choral competition in which tripods were awarded, a prize that later also migrated to the Great Dionysia.

$65 I G \mathrm{I}^{3} 963$ with Wilson 2007: 154-155.

66 Himerius tantalizingly connects many of the elements explored here for Ode 16 and the Thargelia (springtime, swans, the Hebrus, and the Ilissos) in his Orations 47.3-4 (pp. 19o191 Colonna): "Now, boys, it is truly spring ... And if swans ever made a song with the Zephyr by the banks of the Ilissos, as they do on the Cayster and the Hebrus, now more than before they will fill the banks with music." 
there. ${ }^{67}$ Building on a supposition that goes back to Jebb, Wilson compellingly argues for Ode 18's performance by a boys' chorus at the Thargelia on both aetiological and formal grounds. ${ }^{68}$ It is also worth noting that, in addition to Ode 18, three of the other five extant poems from the Alexandrian edition of Bacchylides' Dithyrambs, Odes 15, 17, and 19, are connected in some way to Athens. As David Fearn and others have argued, the imagery and characters of Ode 15 call to mind the Panathenaea, while many view Ode 17 as a celebration of Athenian maritime hegemony. ${ }^{69}$ Ode 19 explicitly enjoins the poet to "weave something new in much-loved blessed Athens" (8-10). If we understand Ode 16 as composed for an Athenian chorus in an Athenian cultic context, then Odes $15^{-19}$, that is, all of the surviving poems collected under the rubric of Bacchylides' Dithyrambs, save the Spartan Ode 20, concern Athens.

As Giambattista D'Alessio shows, the Athenians themselves most likely

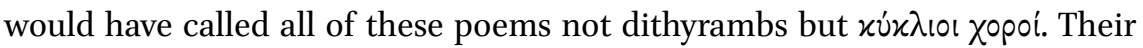
later classification by the Alexandrians as dithyrambs did not have to do with any connection to Dionysiac cult but rather with the poems' extended mythic narratives and a later association that developed between the term dithyramb and the presence of these mythic narratives within certain poems. ${ }^{70}$ Given Ode 16's likely original designation as a $x \dot{x} x \lambda 10 \varsigma \chi 0$ pó and, as I have proposed, its original performance context at the Thargelia, I consider below the implications of these conclusions for our understanding of the poem's genre(s).

\section{Ode 16 and Sophocles' Trachiniae}

Before turning to questions of genre, I must first address the intertextual relationship between Ode 16 and Trachiniae. It is well known that the mythic narrative of Ode 16 coincides with the plot of Sophocles' Trachiniae. Yet, as Jennifer March perceives, the correspondence runs deeper than simply a shared storyline, since the two texts exhibit "distinct similarities of vocabulary, content and

67 Wilson 2007: 174 .

68 Wilson 2007: 173-174 and below.

69 On the performance context of Ode 15 as the Panathenaea, see Maehler 2004: 157-158; Fearn 2007: 257-337. See Fearn 2007: 242, with earlier bibliography, for this interpretation of Ode 17.

70 D'Alessio 2013: 120-122. Thus also Wilson 2007: 174-175 on Bacchylides' Dithyrambs: "Many of these ['dithyrambs'] are in all probability what (at least in an Athenian context) would be termed kyklioi khoroi, for they demonstrate characteristics which prompted the employment of the broader and less explicit category of kyklios khoros, in particular the inclusion of extensive heroic narrative which might have little or nothing to do with Dionysos." See also Fearn 2007: 237-238. 
treatment."71 Numerous scholars and those who, to my mind, have also presented the most compelling arguments, agree on the direction that this intertextual dynamic takes and consider Trachiniae as the source text evoked by the later Ode $16 .{ }^{72}$ The relative priority of Trachiniae holds up from a chronological standpoint. Trachiniae is considered one of Sophocles' earlier plays while Ode 16 , for stylistic and metrical reasons, is thought to have been composed late in Bacchylides' career. The two poets' careers coincided for at least two decades in the 46 os and 45 os, allowing for the two texts to have been composed around the same time, with the lyric poem post-dating the tragedy. ${ }^{73}$

I review here the more salient intersections between the two texts as well as some of the arguments for Trachiniae as the source text for Ode 16. The lyric poem and the tragedy exhibit a remarkable degree of shared vocabulary, a comparable overarching arrangement, and a similarly distinctive treatment of Deianeira.

First, Jennifer March detects the following dictional parallels: Ode 16.16

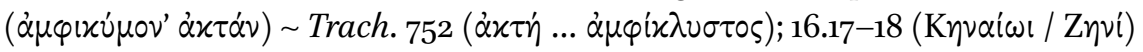

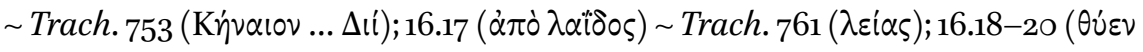

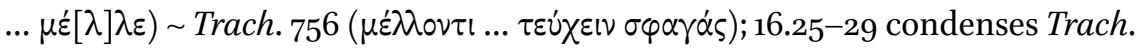
351-368, 380-382; 16.32-33 reworks Trach. 592-593. In addition, as Peter Riemer

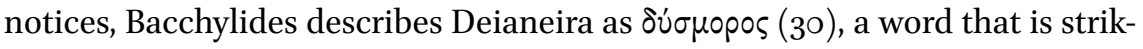
ingly Sophoclean: $\delta \dot{\sigma} \sigma \rho \rho \circ$ s is frequently used by Sophocles, including three times in Trachiniae alone, but is rare in the extant works of other tragedians. ${ }^{74}$

Second, in terms of their similar arrangement, the diptych structure of Ode 16's antistrophe, devoted to Heracles, and epode, devoted to Deianeira, mirrors in reverse order Trachiniae's own configuration, with half of the play devoted to Deianeira and half to Heracles. ${ }^{75}$ Third, a number of scholars also observe that Bacchylides portrays Deianeira in a distinctly tragic, or more precisely, Sopho-

71 March 1987: 62.

72 In addition to March 1987, see Pfeijffer 1999a: 52, Riemer 200o, and Maehler 2004: 167. Contra Kyriakou 2011 and Carawan 200o. As Pfeijffer (1999a: $5^{2}$ ) rightly asserts, the dictional parallels between the two texts are too close for the theory of a common source for both texts to be plausible (cf. Davies 1991: xxxii; Zimmermann 1992: 74-76; Kyriakou 2011: $538)$.

73 On the issue of the relative dating of the two texts, see Pfeijffer 1999a: $5^{2}$ and Riemer 20oo: 170-173, both with earlier bibliography.

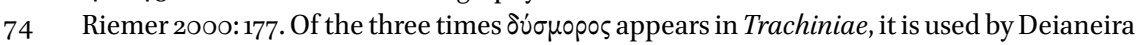
herself to describe Iole (466), by Hyllus in describing Lichas in his speech to Heracles (775, notably the very speech which Ode 16 encapsulates; see below), and by Heracles in describing himself (1005).

Riemer 2000: 173; Kyriakou 2011: 537. 
clean manner. ${ }^{76}$ In Trachiniae, Deianeira is characterized as a passive, fearful woman who, deluded by the belief that Nessus has entrusted her with a lovecharm, unwittingly kills Heracles. This Deianeira stands in stark contrast to pre-Sophoclean versions of the mythic character, including that of Bacchylides' own earlier Ode 5, as a woman who actively desires to kill her husband and whose self-conscious murderous tendencies cast her as another Clytemnestra. ${ }^{77}$

These observations make the tragedy's relative priority probable, but, as Ilja Leonard Pfeijffer rightly argues, Ode 16's evocation of Trachiniae is not only possible but also "highly functional." ${ }^{8}$ For Bacchylides' treatment of the myth of Heracles and Deianeira is so allusive that, without prior knowledge of Sophocles' idiosyncratic tragedy, the precise meaning of several of Ode 16's references would be difficult or even impossible to discern. Thus Bacchylides' audience would have no way of knowing to what Deianeira's $\mu \hat{\tau} \tau \imath \nu(25)$ and Nessus' $\delta \alpha t-$

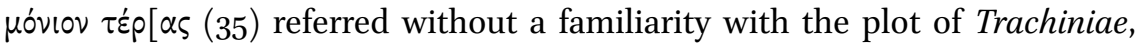
since Deianeira's plan of using Nessus' poisoned blood as a love charm seems to have been Sophocles' innovation. ${ }^{79}$ Moreover, as Pfeijffer observes, Ode 16's dictional similarities with the tragedy conjure, above all, one crucial scene, the beginning of Hyllus' speech to Deianeira (Trach. $75^{\circ}-762$ ). The opening of this speech, just like Ode 16's antistrophe, narrates Heracles' preparations for sacrifice at Cenaeum. As Pfeijffer emphasizes, what Hyllus's speech and Ode 16 both capture in these lines are Heracles and Deianeira in their "final moment[s] of ignorance" before they learn of the deadly properties of Deianeira's gift. ${ }^{80}$

76 See Kamerbeek 1959: 6; Schwinge 1962: 132; Hoey 1979: 215; Easterling 1982: 16; March 1987: 63; Pfeijffer 1999a: 52; Maehler 2004: 166-167.

77 See especially March 1987: 62-71 and Carawan 2000: 191-195. We might note here that Deianeira's very name ("Man-slayer") suggests a more ruthless, pre-Sophoclean past.

78 See Pfeijffer 1999a: 51-55, with quotation from p. 55 .

79 Maehler 1997: 155-156 and 2004: 167.

8o Pfeijffer 1999a: 53. Pfeijffer (1999a: 53-55) argues that the function of Bacchylides' allusions is to thematize the ignorance experienced by Heracles and Deianeira in this scene. Without recourse to Trachiniae, these allusions make the audience of Ode 16 themselves ignorant of exactly what the antistrophe and epode are narrating. In this way, by placing the precise meaning of these allusions "outside the text," Bacchylides effects the audience's empathy for Heracles' and Deianeira's own ignorance. Yet, by triggering their knowledge of Trachiniae as the source text, Bacchylides' audience also experiences dramatic irony. That is, through Trachiniae, the audience is also able to make sense of Ode 16's narrative so that they anticipate the looming events that the characters, without knowledge of the future, cannot (i.e., Heracles' death by the poisoned robe, Deianeira's awareness of her actions). 
In short, Ode 16, beyond merely evoking Trachiniae through its intertextual allusions, depends on Trachiniae in order to be understood fully. Further, what Pfeijffer's study especially highlights is the way in which Ode 16's mythic narrative does not just relay a portion of Trachiniae but encapsulates, in a highly compressed fashion, the tragedy in its entirety. As Pfeijffer perceives, Hyllus' speech, on which Ode 16's narrative is based, forms the "dramatic centre" of the play. ${ }^{81}$ What is more, Ode 16 's concluding sentence calls to mind the entire narrative arc of Trachiniae by alluding both to its end (Deianeira's death) and its inception (the moment she accepts the fateful gift from the centaur Nessus) ${ }^{82}$ We might even compare the disjunction in the focalization between Heracles in the antistrophe and Deianeira in the epode to the fact that in Trachiniae the husband and wife never meet on stage. Finally, Deianeira's own qualities in Ode 16, equal parts ignorance and jealousy, embody the Sophoclean characterization of her "in a nutshell." ${ }^{83}$ Bacchylides does not merely allude to Trachiniae but captures it in its totality so that Ode 16's antistrophe and epode become, as it were, a Trachiniae in miniature.

How can we account for Ode 16's prominent embedding of Trachiniae? We can approach an answer from two different angles, one that attends to Ode 16's specific ritual occasion and, at a more general or abstract level, one that considers questions of genre. For the purposes of this paper, I will focus on some questions of genre but before doing so I would like to offer briefly a way of accounting for this feature that engages with its ritual occasion.

I return again to the observation that Ode 16's antistrophe and epode appropriate, above all, language from the beginning of Hyllus' speech to Deianeira (Trach. 750-762). Accordingly, we can say that Trachiniae's Hyllus himself is evoked at this moment in the lyric poem. As other scholars have noted, in Trachiniae, Hyllus is an ephebic character whose successful transition to adult male status crucially requires Heracles' recognition of him as his son and heir. ${ }^{84}$ As Victoria Wohl asserts, "legitimacy is identity for Hyllus-hence the urgency of the repeated exhortations for him to be "a true son" (1064, 1129, 1157-1158,

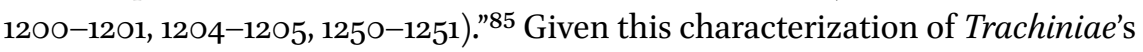
Hyllus, the Thargelia possesses tantalizing explanatory power for the promi-

\footnotetext{
81 Pfeijffer 1999a: 53 .

82 Pfeijffer 1999a: 54 .

83 Hoey 1979: 215, quoted by Pfeijffer 1999a: 54 .

84 See especially Wohl 1998: 11-16.

85 Wohl 1998: 12. Trachiniae's obsessive concern with the bond between father and son is even registered at the dictional level: by Wohl's (1998: 14) count, the word "father" and its cognates occur twenty-three times in the last 307 lines of the play. In this context, I also note that, in Ode 16, Heracles' own patrilineage is doubly determined. Even in the compressed
} 
nence of Hyllus' speech in Ode 16. For the occasion of the Thargelia seems to have been the context in which at least one Atttic phratry gathered to receive new constituents by publicly acknowledging legitimate and adopted sons presented by their fathers. ${ }^{86}$ Wilson in fact applies a comparable logic to bolster an older suggestion that Bacchylides' Ode 18 was performed at the Thargelia. That ode portrays Theseus as a "boy on the cusp of manhood" ( $\pi \alpha \hat{\imath} \delta \alpha \ldots \pi \rho \omega$ $\theta \eta \beta 0 v, 5^{6-57)}$ and showcases explicitly a father's (Aegeus') recognition of his legitimate son (Theseus). ${ }^{87}$

Bacchylides' choice of Trachiniae as the specific tragedy to embed in his lyric poem may thus be informed by Hyllus' ephebic characterization in the tragedy as well as the significance it places on the father-son relationship, both of which suggest fitting mythical counterparts to an important ritual component of the Thargelia. Now, however, I would like to spend the remainder of the paper thinking about Ode 16's inclusion of Trachiniae in terms of genre. In the next section, I will propose that Bacchylides uses the play as a representative of the genre of tragedy in order to respond to tragedy's status as a "super-genre."

\section{Genre at Athens}

If Ode 16 was indeed performed at the Thargelia, fifth-century Athenians would

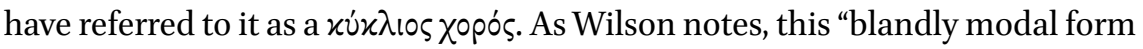
of expression" places emphasis on the configuration of the chorus itself and, in so doing, avoids specific associations with a particular genre or cult, a point to which I will return below. ${ }^{88}$ The phenomenon of designating certain songs simply as $x u ́ x \lambda 10$ ¿ $\chi 0$ poi also provides further evidence for the complex and shifting nature of Greek lyric genres and their frequent tendency to resist assignment to unambiguous generic categories. ${ }^{89}$

Given the challenge of determining the genre of a poem designated as a

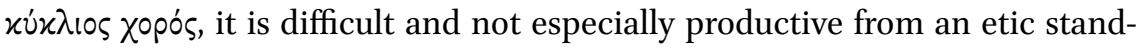
point to attempt to assign Ode 16 a generic label. What we can do instead is consider whether Ode 16 itself tells us anything about genre. As we have already seen, Ode 16 presents us with a vision of Apolline polyphony, a vision

narrative of the ode's antistrophe, Bacchylides makes room to mention Heracles' own two fathers: Heracles is identified as the "son of Amphitryon" (15) and is about to sacrifice to his immortal father, Zeus (18).

86 See Wilson 2007: 174, citing Lambert 1993: 216-217 and Parker 1996: 104-109.

87 Wilson 2007: 172-174.

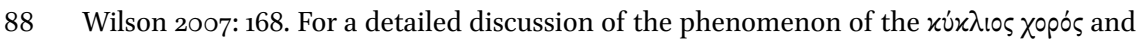
its relationship to dithyramb, see Fearn 2007: 163-225; D'Alessio 2013.

89 See also the Introduction and Weiss in this volume. 
in which the poem's polyphony comprises the sum total of interconnected but autonomous songs. At the level of genre, we might also think of this same vision as one of generic hybridity. The only explicit reference within the poem to genre is the reference to paeans at line 8. But, as Bacchylides stages it, this form of singing for Apollo is marked off, and so implicitly set up as distinct, from both the preceding description of swan song and the song that erupts at line 13, the mythic narrative of Heracles and Deianeria. That is to say, Ode 16's sequence of autonomous songs seems also to be a sequence of generically differentiated songs..$^{90}$

In Part I we found that this sequence of songs was inextricably bound to a sequence of separate geographical spaces, as the poem moved from the Hebrus to Delphi and, finally, to Athens. I would refine that description here and suggest that in Ode 16 geographical location also appears inextricably bound to, perhaps even a generative force behind, individual genres. In other words, generic hybridity is achieved in the poem precisely by moving between physical spaces. One effect of this movement, I suggest, is to drive home the differences between songs.

If Ode 16 indeed conceives of the relationship between genre and location in this way, then the poem simultaneously positions itself in sharp contrast to the form of generic hybridity found in Attic tragedy, including Trachiniae. As Naomi Weiss demonstrates, tragedy can be thought of as a hybrid genre or, more aptly still, as a "super-genre" that commandeers and incorporates an array of different lyric genres by putting them to work in the service of a given play's own narrative. ${ }^{91}$ Weiss' insight can be connected to Barbara Kowalzig's observation that a number of tragic choral odes of Sophocles and Euripides initially give the impression of honoring the cult of a particular god before transforming into a song for Dionysus, the god in whose honor the tragedy itself is being performed. ${ }^{92} \mathrm{~A}$ choral ode from Trachiniae displays both of these qualities $\left(205^{-224)}\right.$ :

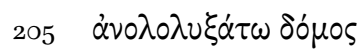

$\dot{\varepsilon} \varphi \varepsilon \sigma \tau i 0 ı \varsigma \alpha \lambda \alpha \lambda \alpha \gamma \alpha \hat{i} \varsigma$

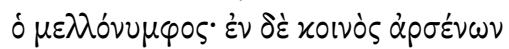

9o Recall here as well the epinician resonance of the strophe's metapoetic opening which evokes yet another genre in this poem and is also tied to a distinct location (Pieria).

91 Weiss (this volume). See too her helpful characterization of early tragedy as an "amalgamation of different types of choral song, interspersed with actors' dialogue (and occasionally actors' song)" (Weiss [this volume] p. 167).

92 Kowalzig 2007a. Other examples of such songs noted by Kowalzig are Soph. OT 151-215 and Ajax 693-718. 


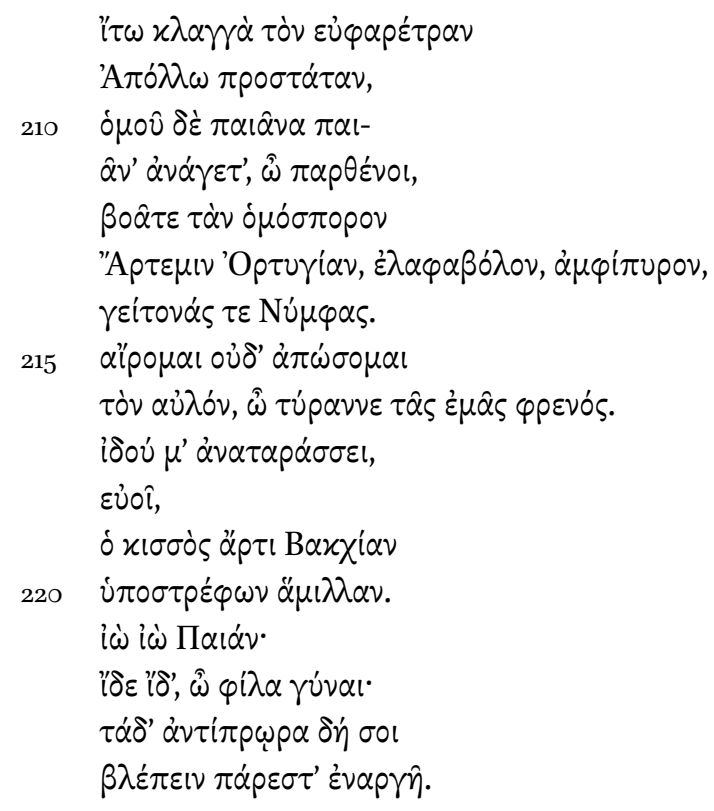

Let the house that is about to be ready for marriage utter a shout of ololuge, with shouts of alalai at the hearth! And let a shared song from the men go up for Apollo of the beautiful quiver, the guardian, and you, maidens, lift up together a paean, a paean, call upon his sister Artemis of Ortygia, shooter of deer, bearer of twin torches, and her neighbors the Nymphs. I am raised up and I will not spurn the aulos, tyrant of my mind. See, it rouses me to frenzy - euoi! — the ivy whirling me around just now in the Bacchic competition. Io, io, Paian! See, see, dear woman: you can behold these things face to face with clarity.

The choral ode's opening invocations to Apollo and Artemis and the appeals for paeans yield to Dionysus' aulos and ivy, the movements of Bacchic dance, and the god's ritual cry of euoi. The passage thus showcases well Dionysus' intrusive tendencies in certain tragic choral odes. And yet, in this instance, it is also worth noting that the choral ode's paeanic element is not lost, since the chorus returns to Apollo with a final outburst of io, io, Paian. The final product is a fusion of paeanic and dithyrambic markers, a kind of generic synthesis or, to use Weiss' term, amalgamation. ${ }^{93}$ This oscillation, in other words, differs sig-

93 See Weiss (this volume) for further discussion of the significance of this ode's generic hybridity. 
nificantly from the interest in maintaining boundaries between autonomous songs that I have suggested for Ode 16.

Tragedy's capacity for generic fusion can also be related to Kowalzig's and Leslie Kurke's work on exposing the ways in which tragedy boldly alters myths and rewrites cultic aetiologies of gods and heroes more readily associated with other Greek communities. ${ }^{94}$ That is, Attic tragedy routinely extracts and combines material from other locations. For example, Kowalzig reveals how Ajax undergoes a process of "Athenianization" in Sophocles' play while Euripides's Hippolytus takes a Troezenian myth and turns it into an explicitly Athenian one. ${ }^{95}$

Tragedy does not necessarily observe the local nature of myth and cult. ${ }^{96}$ We can view tragedy, then, as a genre that both freely mixes lyric genres and freely usurps non-Athenian mythic and cultic traditions that belong to other places. By contrast, in its sequence of songs, Ode 16 maintains, even valorizes, the integrity of what tragedy collapses, namely, the autonomy of generically different songs and the inviolable relationships between these songs and the individual communities to which they belong. ${ }^{97}$ From this perspective, Ode 16 's extended evocation of Trachiniae amplifies its own divergence from tragedy's construction as a super-genre.

The distinction between Ode 16's and tragedy's approaches to genre is thrown into still greater relief if we incorporate Wilson's proposal for the performance venue of the Thargelia's choral contests. Following Claudine Leduc, Wilson questions whether the sanctuary of the Pythion and the neighboring banks of the Ilissos would have provided sufficient space for choruses of fifty men and boys and a large gathering of spectators. ${ }^{98}$ As Wilson notes, "The alternative would be to imagine that the performances were held in the theatre of Dionysos, at least from a date when that had become 'the' place for large-scale choral contest in Athens." ${ }^{\text {99 }}$ This possibility is supported by evidence suggesting that the Athenian assembly met at the theater of Dionysus following the Thargelia to review conduct at the festival, especially any charges

\footnotetext{
94 See Kowalzig 2004 and 20o6; Kurke 2013b.

95 Kowalzig 2006. See also Anderson 2015, who argues that Aeschylus in his Eleusinians shifts the burial place of the Seven against Thebes from Thebes to Eleusis.

96 See especially Kurke 2013b and her discussion of Pindar's Pythian 11 as a response to "tragedy's tendency to displace and deracinate for its own purposes cults that properly belong to other communities" (132).

97 See Weiss (this volume), however, for the ways in which tragedy also leverages the distinctions between different lyric genres in order to shape its dramatic narratives.

98 Wilson 2007: 163, following Leduc 2001: 24-25.

99 Wilson 2007: 163.
} 
of misconduct. ${ }^{100}$ This choice of location for the assembly could imply that the Thargelia's choral performances had also taken place there. It is also worth recalling that the Thargelia took place only two months after the Great Dionysia and thus followed closely on its heels in the calendar of major Athenian religious festivals. From the perspective of fifth-century Athenians, this (possible) spatial and (definite) temporal correspondence would have intensified the potency of Ode 16 as a deliberate response to tragedy in general and Trachiniae in particular. ${ }^{101}$

At the same time, I would contend that Ode 16 does not ultimately position itself as hostile to tragedy's agenda of genre mixing and appropriation. In this respect, Ode 16 differs from several of Pindar's epinicia that do engage in what we might call a polemics of genre with Attic tragedy. ${ }^{102}$ In these epinician examples, Pindar overhauls and rehabilitates imagery and themes from tragedy and then reincorporates them into an epinician ideology. By contrast, Bacchylides does not reject Trachiniae but rather captures it in its entirety, rendering its central dramatic features and characterizations in miniature. Ode 16 seems to set itself up not as a denunciation of but as a counterbalance to tragedy's own generic hybridity. In order to clarify this distinction, I turn finally to a crucial paradox within the poem.

As I argued above, with the onset of the antistrophe, Ode 16 not only shifts to a new type of song and a new group of singers but also shifts to a new location-Athens. Yet Athens, unlike the two other locations of performances in the poem, the banks of the Hebrus and Delphi, is not identified by name. Instead, the antistrophe switches locations, not by explicitly naming Athens but by opening up into the type of choral performance that is performed in and distinctive to Athens, namely, Attic tragedy. At the level of genre, we can view

100 Wilson 2007: 163, citing Dem. 21.10 (the law of Evagoras) with MacDowell 1990 and Scafuro 2004. As noted above, epigraphic evidence seems to indicate that the choral contests of the Thargelia were in full-swing by the mid-fifth century and thus would have counted as a "large-scale choral contest" necessitating the larger space of the theater of Dionysus.

101 Although, as I understand it, the whole of Ode 16 is in honor of Apollo, Dionysus does seem to lurk beneath the surface of the poem in several important ways. With its evocation of Trachiniae, Dionysus is implicitly present as the god whom that tragedy honored. We might also think of Dionysus as present if the choral contests of the Thargelia, even as they honored Apollo Pythios, were performed at the theater of Dionysus. Finally, as scholars have noted, the Thargelia itself appears to have contained a number of Dionysiac components, including an association between the god and the Thargelia's scapegoat ritual (see Wilson 2007).

102 See especially Kurke 2013b for Pindar's ideological response to tragedy's strategies, including its dissolution of traditional ties between cults and communities in Pythian 11. See also Foster 2017 on Pythian 8. 
Ode 16's antistrophe and epode as a highly compressed distillation or snapshot of a tragedy, a distinctly Athenian form of song. ${ }^{103}$ I would like to connect this

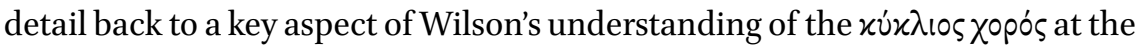
Thargelia. Wilson contends that in fifth-century Athens the use of this modal term and thus the avoidance of classification by genre for certain choral lyric songs allowed these songs to be exported to other performance settings within the Athenian empire:

The effect (and probably the aim) was to make the extremely malleable circular chorus available at the heart of the league and empire to forge and validate in performed myth the city's hegemonic cultural and political identity — and, moreover, to involve the allied states themselves in the performance. ${ }^{104}$

Building on this point, I suggest that by excluding the name of Athens from the poem, Bacchylides makes the tragedy embedded in Ode 16 accessible to non-Athenian audiences and opens it up for export to other communities. This move, however, creates a paradox: on the one hand, as we have seen, Ode 16 establishes and privileges the autonomy of independent locations and their attendant, distinctive songs. In so doing, it positions itself in contrast to tragedy's strategy of collapsing these very distinctions and of upending the relationship between individual places and song. On the other hand, by not explicitly identifying Athens, the poem allows for the location of the present performance in the hic et nunc to be anywhere. What this means is that the poem's chorus, wherever it may be, sings in the antistrophe and epode a miniature tragedy, a uniquely Athenian song. Thus, while the poem promotes the integrity of distinct locations, it simultaneously allows for places beyond Athens to partake in, even to appear willing to produce, a genre distinctive to Athens. We might think of Ode 16's strategy as the inverse of tragedy's own tendencies. Just as tragedy as a super-genre appropriates and folds into itself other songs with mythic and cultic material more readily tied to other communities, Ode 16 finds a means for tragedy to enter these other communities, to be exported beyond the theater of Dionysus. ${ }^{105}$ This final suggestion complicates Ode 16's

103 One can see now why scholars have traditionally considered this portion of Ode 16 a dithyramb. But I would emphasize that Bacchylides is not enlisting the genre of dithyramb here but that of tragedy itself. This evocation of tragedy is in play even as the poem itself is ultimately in honor of Apollo, not Dionysus.

104 Wilson 2007: 175-182, quotation from 175 .

105 In this context, it is worth mentioning an Athenian administrative account that lists 
vision of Apolline polyphony as some number of autonomous songs. For even as the poem valorizes individual songs and their rootedness in particular physical spaces, it simultaneously leaves us with the impression that the cosmos these songs inhabit ultimately skews Athenian, that Athenian songs get to be sung everywhere.

I hope to have shown how an overreliance on Alcaeus fr. 307c as a paradigm for Ode 16's strophe has led to the entrenched assumption that the poem was performed for Dionysus at Delphi by a Delphian chorus awaiting Apollo's return from the Hyperboreans. By attending closely to the strophe and drawing on new parallels, I have painted a different picture, namely that the poem presents a sequence of generically distinct songs, all tied to discrete locations and all sung in honor of Apollo. As such, the poem as a whole amounts to what we might think of as an instance of Apolline polyphony and deploys a motif of singers performing their own distinctive songs for the god. Once we set aside the myth of the Hyperboreans, it also becomes easier to see that there is no indication of the poem's performance at Delphi. Instead, I proposed Athens as the site of the poem's performance and the Thargelia, the annual festival of the Athenian cult of Apollo Pythios, as its specific ritual occasion. Continuing with the poem's connection to Athens, I argued that Bacchylides' intertextual reliance on Sophocles' Trachiniae allows us to see the poem as a conscious response to tragedy's conflations. Ode 16 insists on a polyphony of autonomous songs in opposition to tragedy's amalgamations and appropriations. Yet, in the end, it does not oppose that genre's strategies. Rather, Ode 16's encapsulation of the genre of tragedy within itself offers a way of transmitting, of exporting tragedy beyond the borders of Athens while, or perhaps even because, it simultaneously promotes the importance of the autonomy of song and its attachment to particular places.

A final, fitting detail concerning the Thargelia must be mentioned. The Thargelia's choral contests for Apollo Pythios consisted of five choruses of men and five of boys. As such, they seem to have imitated on a smaller scale the ten choruses each of men and boys at the Great Dionysia. ${ }^{106}$ A remarkable and unparalleled feature accounts for the difference between the five choruses at the Thargelia and the ten choruses at the Great Dionysia in each age category.

expenses for exporting from Athens tripods as prizes, sacrificial bulls, and choruses on a cargo ship to the Delian festival ( $I G \mathrm{II}^{2} 1635 \mathrm{a}$, especially $33^{-}-39$ with Wilson 2007: 175). We might see Ode 16 as another piece of cargo to be exported abroad, an image that recalls and gives a new dimension to the poem's own opening image of a cargo ship of songs.

Wilson 2007: 156 . 
In contrast to the Great Dionysia, where each of the ten Cleisthenic tribes provided a chorus of men and a chorus of boys, at the Thargelia, the ten tribes were paired off in order to make a total of five choruses for each age group. This pairing was random and accomplished by lot until roughly the 370 . $^{107}$ Consequently, each Thargelian chorus comprised a tribal pair who performed as a "team." 108 This unique feature of the Thargelia perfectly captures the relationship between autonomy and polyphony that I have explored in Ode 16. For each Cleisthenic tribe within the pair surely viewed itself as autonomous, its membership in a particular tribe an irreducible aspect of its identity. And yet, for the sake of the competition, each tribe worked together to sing and dance as a single chorus with its tribal partner. That is, even at the level of its performers, Ode 16 offers a vision of synchronized autonomous parts singing and dancing in polyphonous collaboration in honor of Apollo.

107 Wilson 2007: 156.

108 Wilson 2007: 156. 